\title{
Ranges of moisture-source temperature estimated from Antarctic ice cores stable isotope records over glacial-interglacial cycles
}

\author{
R. Uemura ${ }^{1, *}$, V. Masson-Delmotte ${ }^{1}$, J. Jouzel ${ }^{1}$, A. Landais ${ }^{1}$, H. Motoyama ${ }^{2}$, and B. Stenni ${ }^{3}$ \\ ${ }^{1}$ IPSL-Laboratoire des Sciences du Climat et l'Environnement (LSCE/IPSL), UMR8212, CEA-CNRS-UVSQ, 91191, France \\ ${ }^{2}$ National Institute of Polar Research, Research Organization of Information and Systems, 10-3, Midoricho, Tachikawa, \\ Tokyo 190-8518, Japan \\ ${ }^{3}$ Department of Mathematics and Geosciences, University of Trieste, via E. Weiss 2, 34128, Trieste, Italy \\ *now at: Department Chemistry, Biology and Marine Science, Faculty of Science, University of the Ryukyus, 1 Senbaru, \\ Nishihara, Okinawa, 903-0213, Japan
}

Correspondence to: R. Uemura (ruemura@ sci.u-ryukyu.ac.jp)

Received: 27 December 2011 - Published in Clim. Past Discuss.: 30 January 2012

Revised: 22 May 2012 - Accepted: 31 May 2012 - Published: 29 June 2012

\begin{abstract}
A single isotope ratio $\left(\delta \mathrm{D}\right.$ or $\left.\delta^{18} \mathrm{O}\right)$ of water is widely used as an air-temperature proxy in Antarctic ice core records. These isotope ratios, however, do not solely depend on air-temperature but also on the extent of distillation of heavy isotopes out of atmospheric water vapor from an oceanic moisture source to a precipitation site. The temperature changes at the oceanic moisture source $\left(\Delta T_{\text {source }}\right)$ and at the precipitation site $\left(\Delta T_{\text {site }}\right)$ can be retrieved by using deuterium-excess $(d)$ data. A new $d$ record from Dome Fuji, Antarctica spanning the past $360000 \mathrm{yr}$ is presented and compared with records from Vostok and EPICA Dome C ice cores. In previous studies, to retrieve $\Delta T_{\text {source }}$ and $\Delta T_{\text {site }}$ information, different linear regression equations were proposed using theoretical isotope distillation models. A major source of uncertainty lies in the coefficient of regression, $\beta_{\text {site }}$ which is related to the sensitivity of $d$ to $\Delta T_{\text {site }}$. We show that different ranges of temperature and selections of isotopic model outputs may increase the value of $\beta_{\text {site }}$ by more than a factor of two. To explore the impacts of this coefficient on reconstructed temperatures, we apply for the first time the exact same methodology to the isotope records from the three Antarctica ice cores. We show that uncertainties in the $\beta_{\text {site }}$ coefficient strongly affect (i) the glacial-interglacial magnitude of $\Delta T_{\text {source }}$; (ii) the imprint of obliquity in $\Delta T_{\text {source }}$ and in the site-source temperature gradient. By contrast, we highlight the robustness of $\Delta T_{\text {site }}$ reconstruction using water isotopes records.
\end{abstract}

\section{Introduction}

Climate records preserved in Antarctic ice cores provide important clues for the climate history over the several hundred thousand years. Among many deep ice cores from Antarctica, Vostok (Petit et al., 1999), EPICA Dome C (hereafter EDC) (EPICA Community Members, 2004; Jouzel et al., 2007) and Dome Fuji cores (hereafter DF) (Watanabe et al., 2003) have provided climate and environmental information covering multiple glacial-interglacial cycles. $\delta \mathrm{D}$ and $\delta^{18} \mathrm{O}$ of water are widely used as proxies for air-temperature, albeit with uncertainties in temperature reconstructions arising from possible changes in precipitation intermittency (Steig et al., 1994; Sime et al., 2009; Laepple et al., 2011), ice sheet elevation (Masson-Delmotte et al., 2011), or evaporation conditions (Boyle, 1997).

The latter source of uncertainty can be explored using a second-order isotopic information available through deuterium-excess $\left(d=\delta \mathrm{D}-8 \times \delta^{18} \mathrm{O}\right)$ (Dansgaard, 1964). The $d$ parameter mainly gives access to processes affected by kinetic fractionation and has been used as a tracer of evaporation conditions such as ocean surface temperature and relative humidity in moisture source ocean (Merlivat and Jouzel, 1979). The $d$ value of modern atmospheric vapor above the Southern Ocean shows a clear dependency on sea surface temperature and relative humidity at the moisture source (Uemura et al., 2008). The initial information is then modified by subsequent meteorological processes

Published by Copernicus Publications on behalf of the European Geosciences Union. 
(e.g. precipitation, snow formation, and cloud microphysics). The Antarctic precipitation $d$ value is therefore also affected by kinetic fractionation during the snow formation, whose importance is expressed by a supersaturation function (Jouzel and Merlivat, 1984; Risi et al., 2010; Winkler et al., 2012), and by equilibrium distillation at very cold temperatures as well as the amount of rainout from the source to sink.

At first order, past variations of $\delta \mathrm{D}$ and $d$ in ice cores are assumed to mostly depend on polar temperature $\left(\Delta T_{\text {site }}\right)$, moisture source temperature $\left(\Delta T_{\text {source }}\right)$, and ocean isotopic composition $\left(\delta^{18} \mathrm{D}_{\mathrm{sw}}\right.$ and $\left.\delta^{18} \mathrm{O}_{\mathrm{sw}}\right)$. Source and site climatic information can therefore be extracted from ice core $\delta \mathrm{D}$ and $d$ records, using a linear regression model based on the Rayleigh distillation isotopic model and/or more sophisticated models (Vimeux et al., 2001; Cuffey and Vimeux, 2001; Stenni et al., 2001, 2010). This dual isotope approach allows corrections to site temperature estimates for moisture source effects. Such site and source temperature inversions have been conducted using different methodologies (e.g. different adjustments of the linear regression coefficients) for Vostok (Cuffey and Vimeux, 2001; Vimeux et al., 2002), EDC (Stenni et al., 2001, 2003, 2010), and EPICA Dronning Maud Land (EDML) (Stenni et al., 2010) ice cores. These studies reveal the importance of obliquity in modulating Vostok source temperature (Vimeux et al., 2002). It has also been shown that source correction enhances the correlation between Vostok $\Delta T_{\text {site }}$ and atmospheric $\mathrm{CO}_{2}$ during glacial inceptions (Cuffey and Vimeux, 2001), and that glacial millennial Antarctic Isotopic Maxima largely reflect changes in site temperature (Stenni et al., 2003). However, there are no common methodologies and are still significant uncertainties about reconstructing site and source temperatures.

Indeed, it is not possible to assess the full range of unknown source parameters (source temperature, relative humidity, wind speed) with only two isotope measurements $(\delta \mathrm{D}$ and $\delta^{18} \mathrm{O}$ ) (Stenni et al., 2010). To overcome this problem, different approaches have been developed to account for the ocean isotope changes and relative humidity effect (Vimeux et al., 2001; Cuffey and Vimeux, 2001; Stenni et al., 2001, 2003). The largest difference between these studies is associated with the coefficient describing the sensitivity of $d$ to $\Delta T_{\text {site, }}$, hereafter $\beta_{\text {site }}\left(=-\partial d / \partial T_{\text {site }}\right)$, for which different studies have used values ranging from $\sim 0.5$ (Cuffey and Vimeux, 2001; Stenni et al., 2001) to 1.2 (Salamatin et al., 2004). In this manuscript, we review the causes for differences in $\beta_{\text {site }}$ and the subsequent impacts on $\Delta T_{\text {source }}$ and $\Delta T_{\text {site }}$ reconstructions for the three central East Antarctic ice cores using published isotope profiles from Vostok and EDC, and a new deuterium excess record from DF.

This manuscript is organized as follows: ice-core data and isotope modeling are described in Sect. 2, while causes for the $\beta_{\text {site }}$ differences and their impacts on $\Delta T_{\text {source }}$ and $\Delta T_{\text {site, }}$, are discussed in Sect. 3 and site and source reconstructions in Sect. 4.

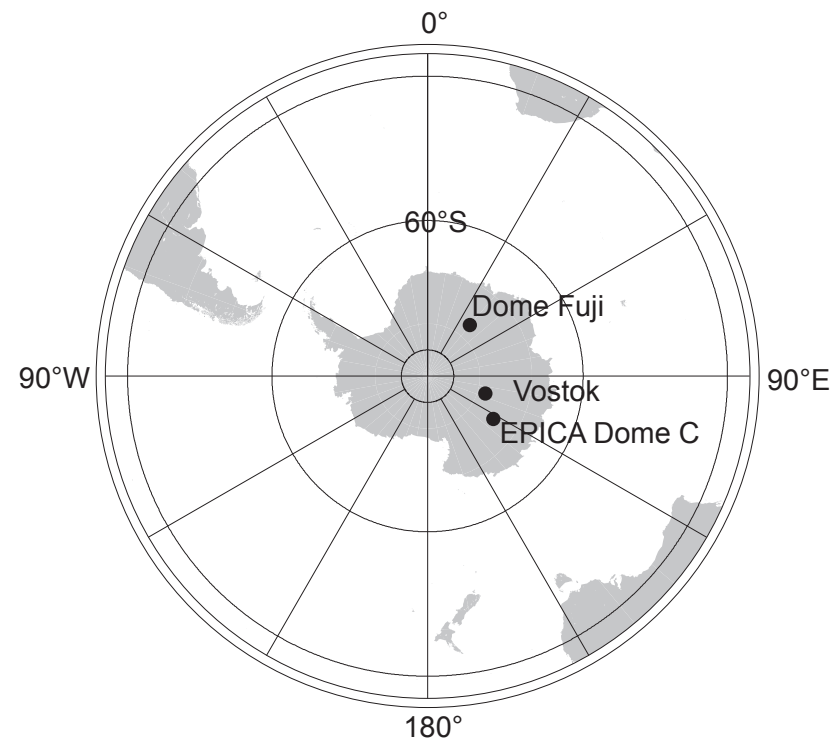

Fig. 1. Locations of the Antarctic ice cores used in this study.

\section{Isotope data and modeling}

\subsection{Ice core isotopic data}

We used the three deep ice cores drilled in East Antarctica, DF, Vostok and EDC. The DF data were extended and revised in this paper (Fig. 1). Two ice cores were drilled at the DF station $\left(77^{\circ} 19^{\prime} \mathrm{S}, 39^{\circ} 42^{\prime} \mathrm{E}\right.$, elevation $\left.3810 \mathrm{~m}\right)$. The first 2503 m-depth core (DF1) was drilled in 1996, and revealed the $\delta^{18} \mathrm{O}$ and $\delta \mathrm{D}$ records back to $\sim 340 \mathrm{kyr}$ BP (thousands of years before present) (Watanabe et al., 2003; Uemura et al., 2004). A second core (Dome Fuji 2nd, DF2) reached near bedrock in 2007 at the depth of $3035.2 \mathrm{~m}$ (Motoyama, 2007), and the $\delta^{18} \mathrm{O}$ record from a $\sim 130$ m-length section (2399.5-2531.5 m depth) core was published (Uemura et al., 2010a). Here, we present $\delta \mathrm{D}$ and $d$ records from the $\sim 130 \mathrm{~m}$ length section of the DF2 core at $10 \mathrm{~cm}$-length sampling from every $50 \mathrm{~cm}(n=265)$. The $\delta \mathrm{D}$ data from the overlapping section (2400-2500 m) of DF 1 and DF2 shows remarkable similarity (Fig. 2).

The DF isotope ratios were measured using an equilibration method (Uemura et al., 2007) at National Institute of Polar Research, Japan. Routine measurements (2006 to 2008) of a reference water sample show that reproducibilities $(1 \sigma)$ of this water are $0.3 \%$ for $\delta \mathrm{D}, 0.04 \%$ for $\delta^{18} \mathrm{O}$, and $0.4 \%$ for $d$. Duplicate analyses for 119 ice core samples confirm these estimates. In order to obtain the revised $d$ record for the entire DF core, a new data set was made by (1) subtracting artificial isotope offsets from the DF1 record (see below) and (2) replacing the DF1 data by DF2 data for the overlapping part (2400-2503 m).

First, there are offsets between DF1 and DF2 $\left(\delta_{\mathrm{DF} 1}-\right.$ $\delta_{\mathrm{DF} 2}=0.8 \%$ or for $\delta \mathrm{D}$, and $0.24 \%$ ofor $\delta^{18} \mathrm{O}$ ). In order to 

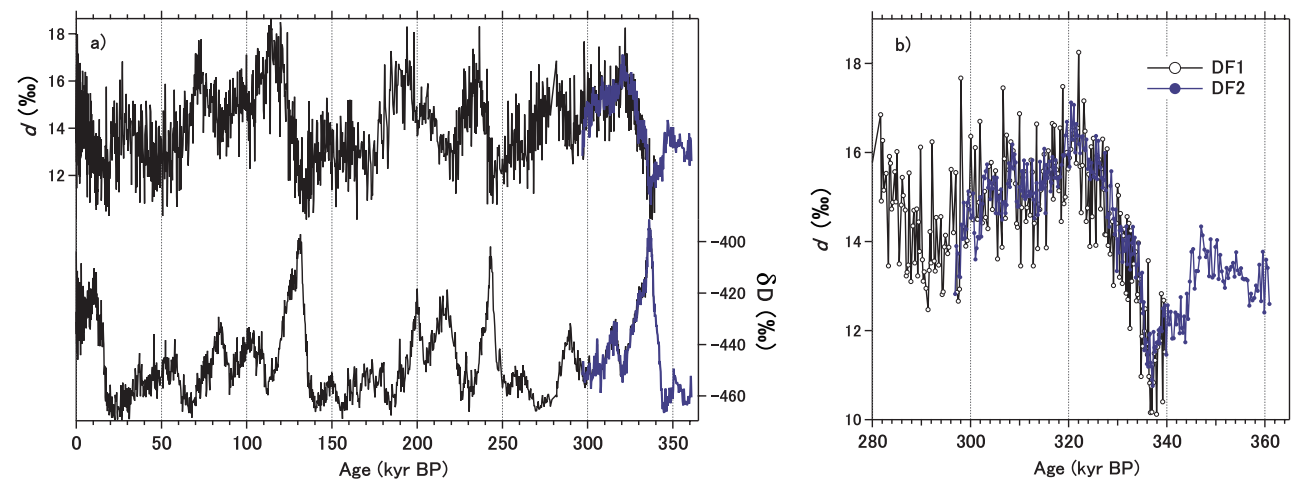

Fig. 2. $\delta \mathrm{D}$ and deuterium-excess records from the DF ice cores. (a) $\delta \mathrm{D}$ and $d$ records from DF1 (black lines) and DF2 (blue lines) cores. (b) Enlarged view of the $d$ records during the overlapping period. Here, $\delta=R_{\text {sample }} / R_{\mathrm{VSMOW}}-1$, and $R_{\text {sample }}$ and $R_{\mathrm{VSMOW}}$ are the isotope ratios $\left(\mathrm{D} / \mathrm{H}\right.$ and $\left.{ }^{18} \mathrm{O} /{ }^{16} \mathrm{O}\right)$ of sample and VSMOW, respectively.

assess the potential causes of this offset, we re-cut and measured the archived DF1 ice ( 60 samples). The re-cut DF1 data are consistent with that of measured DF2 data (i.e. no offset), but lower than that of the old DF1 data. This result suggests that only the "old DF1" data are isotopically enriched slightly than both "re-cut DF1" and "DF2" data due to some artifacts. This is probably caused by problems in the storage of the DF1 samples preserved in glass vials as liquid. Based on our experiment, isotopic enrichment during long term storage may explain half $\left(\sim 0.1 \%\right.$ o for $\left.\delta^{18} \mathrm{O}\right)$ of the observed off-set between DF1 and DF2. So far, we cannot explain the full magnitude of the offset between DF1 and DF2. The offsets of $\delta$ values were subtracted from the published data (Watanabe et al., 2003; Uemura et al., 2004). We should note that the off-set discussed here is systematic, small compared with glacial-interglacial variations ( $1.3 \%$ of full amplitude), and does not affect magnitudes of events. Therefore, the correction applied here does not influence the conclusions of earlier studies.

Second, an enlarged view of the records clearly shows that the $d$ data are less noisy for DF2 than for DF1, suggesting that the precision of the new data is improved by replicate measurements of many ( $\sim 30 \%$ ) samples (Fig. 2). Thus, we replaced DF1 record by DF2 for the overlapping period.

For Vostok $\left(78^{\circ} 30^{\prime} \mathrm{S}, 106^{\circ} 54^{\prime} \mathrm{E}\right.$, elevation $\left.3488 \mathrm{~m}\right)$, the $d$ data span the past $\sim 420 \mathrm{kyr} B P$ (Vimeux et al., 2001). We restricted the ice core comparison over the past $250 \mathrm{kyr}$ because the deepest part of the data is likely affected by changes in ice origin due to ice flow (Vimeux et al., 2001). For the EDC core $\left(75^{\circ} 06^{\prime} \mathrm{S}, 123^{\circ} 23^{\prime} \mathrm{E}\right.$, elevation $\left.3233 \mathrm{~m}\right)$, we used the recently published record spanning over the last $140 \mathrm{kyr}$ BP (Stenni et al., 2010). Another $d$ record from EDML $\left(75^{\circ} 00^{\prime} \mathrm{S}, 00^{\circ} 09^{\prime} \mathrm{E}\right.$, elevation $\left.2892 \mathrm{~m}\right)$ is also available for the same period but was not considered here because of uncertainties in elevation/ice origin impact (Stenni et al., 2010).

Precisions of $\delta^{18} \mathrm{O}$ and $\delta \mathrm{D}$ measurements of both the Vostok and EDC cores are $0.05 \%$ and $0.5 \%$, respectively,
(Vimeux et al., 2001; Stenni et al., 2010) with a final precision of $0.6 \%$ on $d$. Therefore, the analytical accuracies of the 3 ice cores isotopic records are similar. The temporal resolution, which is estimated a using cutting scale combined with a depth-age scale, however, differs between records. The average temporal resolution of the DF data is $\sim 270 \mathrm{yr}$, except for the $\sim 70 \mathrm{yr}$ resolution during the Holocene. At Vostok, the average temporal resolution is $\sim 220 \mathrm{yr}$ for our period of interest (Vimeux et al., 2001). The EDC core shows the highest temporal resolution; $\sim 18 \mathrm{yr}$ for the Holocene, $\sim 50 \mathrm{yr}$ for MIS2 and $\sim 42 \mathrm{yr}$ for MIS5.5 (Stenni et al., 2010). We place the ice core isotopic records on a common age scale in order to be able to make a comparison. As shown in Fig. 3, significant differences (up to $\sim 5 \mathrm{kyr}$ ) exist between the glaciological age scales established for Vostok (GT4 age-scale by Petit et al., 1999) and EDC (EDC3 age-scale by Parrenin et al., 2007) and the $\mathrm{O}_{2} / \mathrm{N}_{2}$ orbital age scale for DF (Kawamura et al., 2007). The age-scale difference between Vostok and DF is $\sim 1 \mathrm{kyr}$ before $80 \mathrm{kyr} \mathrm{BP}$, and increased up to $\sim 5 \mathrm{kyr}$ around $120 \mathrm{kyr} \mathrm{BP}$, and between EDC and DF is $\sim 1 \mathrm{kyr}$ before $80 \mathrm{kyr} \mathrm{BP}$, and increased up to $\sim 4 \mathrm{kyr}$ for the older part. Here, we use the DF age scale as a target and synchronized the Vostok, EDC and our new stacked DF record using visual $\delta$ D matching (Fig. 3). We used 21 tie points for DF-Vostok fitting, and nine tie points for DF-EDC fitting. For the calculation of $\Delta T_{\text {site }}$ and $\Delta T_{\text {source }}$, all the data were re-sampled with 200-yr resolution, which is under-sampling for EDC data, and slightly over-sampling for Vostok and DF data.

Note that this temporal resolution is the result of the sampling strategy, combined with the depth-age scale, resulting from changes in accumulation and thinning. The ability to resolve past high frequency climatic variations also depends on isotopic smoothing caused by diffusion in firn and ice. The diffusion length at EDC was estimated at $8 \mathrm{~cm}$ for MIS11 (Pol et al., 2011), deeper than for our studied periods. For example, the sampling length of about $165 \mathrm{~cm}$ 

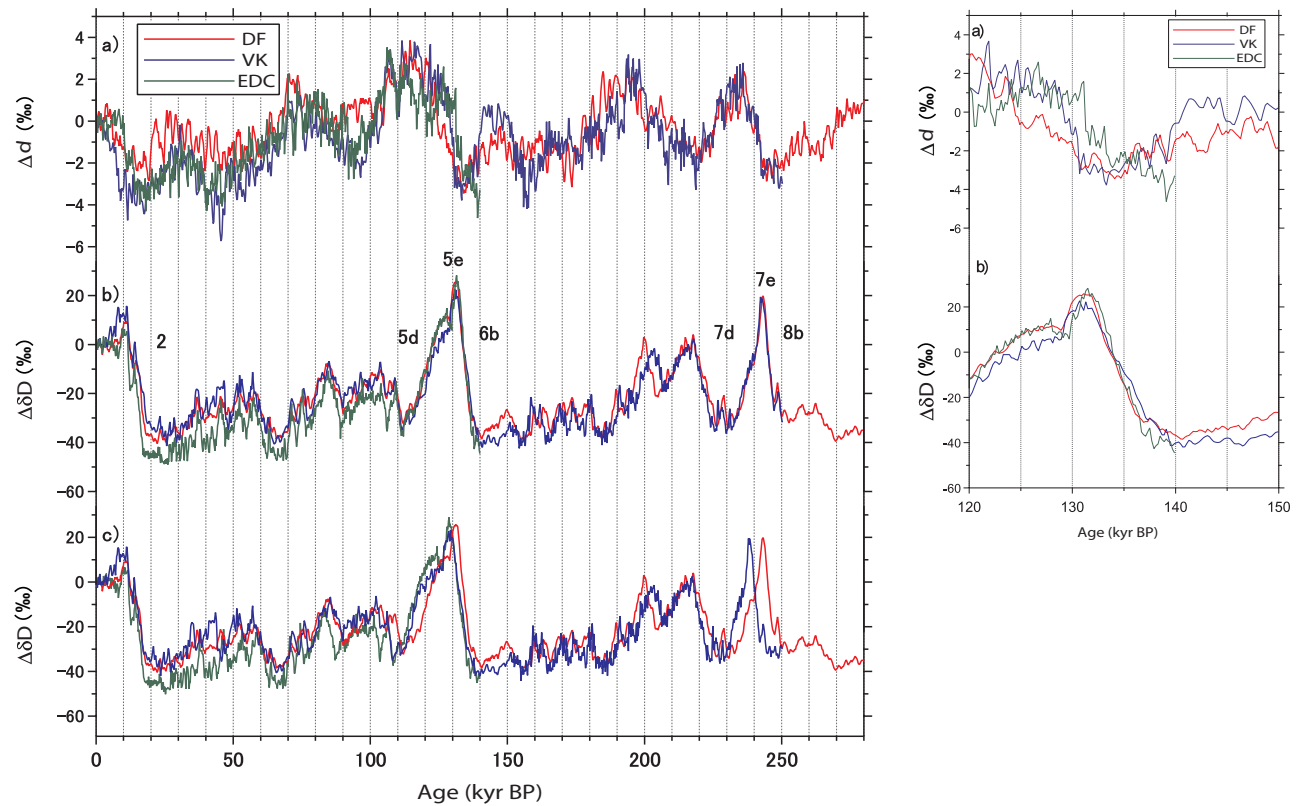

Fig. 3. $\delta \mathrm{D}$ and deuterium-excess records from the DF ice cores. Left panel: (a) Deuterium-excess $(d$ ) records from DF (red line), Vostok (blue line), and EDC (green line) cores plotted on the $\mathrm{O}_{2} / \mathrm{N}_{2}$ orbital age scale for DF. (b) $\delta \mathrm{D}$ records of the three cores plotted on the $\mathrm{O}_{2} / \mathrm{N}_{2}$ orbital age scale for DF. (c) $\delta \mathrm{D}$ records of the three cores plotted on the original age-scales (see text). Numbers indicate corresponding Marine Isotope Stage (MIS) (Tzedakis et al., 2004). Right panel: enlarged view of Termination II. All the isotope ratios are expressed as the deviations $(\Delta)$ from the present (past 2 kyr average) value.

at EDC (at $\sim 1460 \mathrm{~m}$ depth, $\sim 108 \mathrm{kyr} \mathrm{BP}$ ) corresponding to $200 \mathrm{yr}$ resolution.

\subsection{Raw $d$-excess and $\delta D$ data}

The raw $d$ records from the DF, Vostok, and EDC ice cores show common low frequency variability ( $\sim 40 \mathrm{kyr}$ ) (Fig. 2 ). There are periods of pronounced $d$ minima in the older sections (200-250 kyr BP) at DF and Vostok, and both the records show similar variations. A difference can be found during the glacial terminations. From 20 to $10 \mathrm{kyr}$ BP (Termination I), the onset of $d$ increases in DF and Vostok appears to lag that of EDC. From $140 \mathrm{kyr}$ to $130 \mathrm{kyr}$ BP (Termination II), a similar lag is observed (Fig. 3). It is difficult to interpret the raw $d$ record because it is an empirically defined second-order parameter. In fact, a different definition of $d$ parameter can produce different glacial interglacial variations (see Sect. 3 and Appendix A). Climatic interpretation of $d$ will be discussed after inferring $\Delta T_{\text {source }}$ from isotopic data (Sect. 4).

\subsection{Isotope inversion method}

In order to retrieve the climatic information from the isotope ratios, we need to evaluate several coefficients using an isotope model. Sensitivities of $\delta \mathrm{D}$ and $d$ to $\Delta T_{\text {site, }}$, $\Delta T_{\text {source }}$, relative humidity ( $\mathrm{RH}$ ), and ocean isotopic composition $\left(\delta^{18} \mathrm{O}_{\mathrm{sw}}\right)$ were estimated using a mixed cloud isotopic model (MCIM) developed by Ciais and Jouzel (1994).
We used the linear inversion method that is similar to the method used for Vostok (Cuffey and Vimeux, 2001) and EDC records (Stenni et al., 2001, 2003, 2010; Masson-Delmotte et al., 2004).

There are several differences among the inversion methods used for various ice cores. First, the coefficients for the correction for $\delta^{18} \mathrm{O}_{\mathrm{sw}}$ were used as fixed parameters in several studies (Vimeux et al., 2001, 2002; Cuffey and Vimeux, 2001; Stenni et al., 2001). This coefficient is calculated as a function of the isotopic composition of the ice (Vimeux et al., 2001; Jouzel et al., 2003; Kavanaugh and Cuffey, 2003), as follows:

$$
\begin{aligned}
& \delta^{18} \mathrm{O}_{\text {corr }}=\delta^{18} \mathrm{O}_{\text {ice }}-\delta^{18} \mathrm{O}_{\mathrm{SW}} \frac{\left(1+\delta^{18} \mathrm{O}_{\text {ice }}\right)}{\left(1+\delta^{18} \mathrm{O}_{\mathrm{SW}}\right)} \\
& \delta \mathrm{D}_{\text {corr }}=\delta \mathrm{D}_{\text {ice }}-\delta \mathrm{D}_{\mathrm{SW}} \frac{\left(1+\delta \mathrm{D}_{\text {ice }}\right)}{\left(1+\delta \mathrm{D}_{\mathrm{SW}}\right)}
\end{aligned}
$$

Here, $\delta^{18} \mathrm{O}_{\text {corr }}$ and $\delta \mathrm{D}_{\text {corr }}$ are the isotope ratios of the ice $\left(\delta^{18} \mathrm{O}_{\text {ice }}\right.$ and $\left.\delta \mathrm{D}_{\text {ice }}\right)$ corrected for ocean isotope changes $\left(\delta^{18} \mathrm{O}_{\mathrm{sw}}\right.$ and $\left.\delta \mathrm{D}_{\mathrm{sw}}\right)$. An estimate of the global ice volume component of sea-water $\delta^{18} \mathrm{O}$ (Bintanja and Wal, 2008) was used for the $\delta^{18} \mathrm{O}_{\mathrm{sw}}$ record. The $\delta \mathrm{D}_{\mathrm{SW}}$ is calculated on the assumption that $\delta \mathrm{D}_{\mathrm{sw}}=8 \times \delta^{18} \mathrm{O}_{\mathrm{sw}}$. Thus, the $d$ value corrected for the ocean isotope effect $\left(d_{\text {corr }}\right)$ is obtained by $\quad d_{\text {corr }}=\delta \mathrm{D}_{\text {corr }}-8 \delta^{18} \mathrm{O}_{\text {corr }}$. Following recent studies (e.g. Stenni et al., 2010), we apply this correction before conducting the multiple linear regression. 
Second, $\delta \mathrm{D}$ and $d$ in polar precipitation preserve source effects and therefore depend on climatic parameters affecting evaporation kinetics, including $\Delta T_{\text {source }}$ but also relative humidity (RH) and wind-speed regimes (Merlivat and Jouzel, 1979; Petit et al., 1991). For Vostok, the RH effect was explicitly included in the $\Delta T_{\text {source }}$ by using a linear relationship identified in Atmospheric General Circulation Models $\left(\Delta \mathrm{h} \sim-0.4 \Delta T_{\text {source}}\right)$ (Vimeux et al., 2001; Cuffey and Vimeux, 2001). For EDC, the RH effect was not included, restricting the analyses of source effects to $\Delta T_{\text {source }}$ only (Stenni et al., 2001). Here, we adopted the latter approach for the sake of simplicity. Thus, the results of multiple linear regressions can be expressed as

$$
\begin{gathered}
\Delta \delta \mathrm{D}_{\text {corr }}=\gamma_{\text {site }} \Delta T_{\text {site }}-\gamma_{\text {source }} \Delta T_{\text {source }} \\
\Delta d_{\text {corr }}=-\beta_{\text {site }} \Delta T_{\text {site }}+\beta_{\text {source }} \Delta T_{\text {source }}
\end{gathered}
$$

All the $\gamma$ and $\beta$ coefficients are positive numbers expressed in $\%$ o per $\mathrm{K}$. The $\Delta$ represents deviations from the present reference values (in this study "present" is defined as the averaged value of the past $2 \mathrm{kyr}$ ). The $\Delta T_{\text {site, }}$, mean annual temperature at ground level, is calculated from the mean annual temperature of condensation $\left(\Delta T_{\mathrm{c}}\right)$ by assuming a constant relation $\left(\Delta T_{\mathrm{c}}=0.67 \Delta T_{\text {site }}\right)$ (Jouzel and Merlivat, 1984). This is an approximation as the Antarctic inversion strength varies spatially and in time, and with changing weather conditions. Recently, a detailed analysis of the half century long meteorological observations at Vostok allowed to estimate changes in condensation temperature and confirmed the validity of this approach (Ekaykin, 2003).

Finally, kinetic isotope fractionation occurs during ice crystal growth because of super-saturation over ice, and this is parameterized using a linear function of temperature tuned to reproduce the spatial $d$ vs. $\delta$ distribution in Antarctica (Petit et al., 1991). We used a linear function $(\mathrm{Si}=1.020-0.003 T)$ which best reproduces the presentday surface snow $d$ vs. $\delta \mathrm{D}$ distribution from various parts of Antarctica (Masson-Delmotte et al., 2008), and from the Japanese-Swedish IPY 2007/2008 traverse (Fujita et al., 2011) covering the Syowa-Dome F route (Fukui et al., 2010) (Fig. 4). In this study, all the simulations (except for Table 3) were conducted using this fixed super super-saturation function.

\subsection{Present-day isotope tuning}

The first step for estimating the sensitivity coefficients is to fit the model output to the present-day snow isotopic distribution (Fig. 4). An important problem of this tuning is the difficulty to simulate present-day snow isotope ratios by using the MCIM. At the DF site, the present-day (past $2 \mathrm{kyr}$ average $\pm 1 \sigma$ ) isotope ratios are $\delta^{18} \mathrm{O}=-55.09 \pm 0.16 \%$, $\delta \mathrm{D}=-426.3 \pm 1.4 \%$, and $d=14.4 \pm 0.3 \%$. With our MCIM tuning, these isotope ratios can only be reached with a very cold site temperature (i.e. annual mean air temperature at the surface snow), $-61.0^{\circ} \mathrm{C}$, which is significantly lower

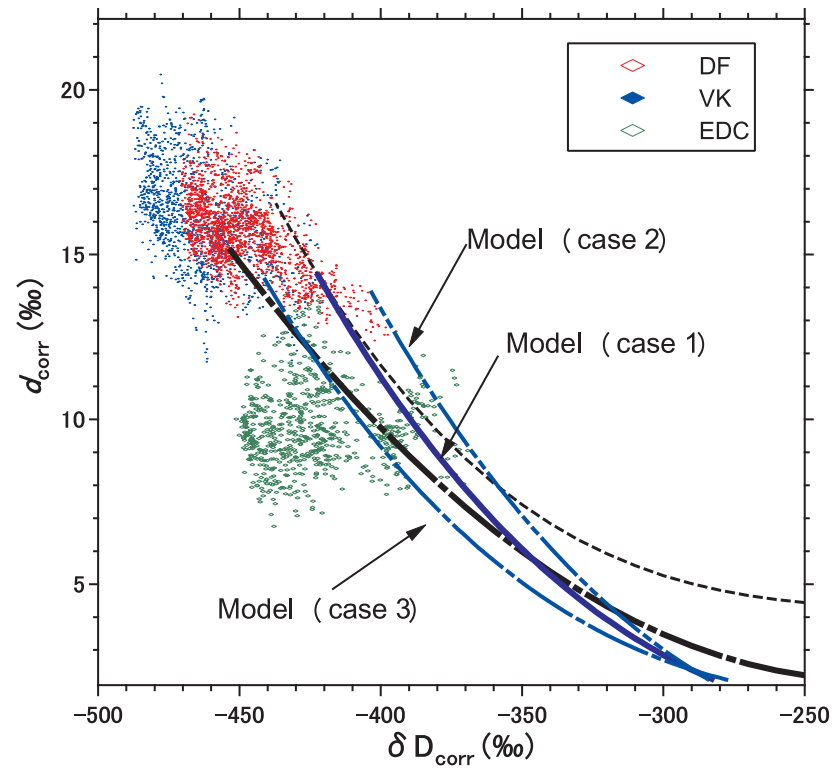

Fig. 4. Isotope ratios of Antarctic surface snow and ice cores. Regression curves of surface snow data from various parts of Antarctica (black dashed-dotted line) (Masson-Delmotte et al., 2008), and from Japanese-Swedish IPY 2007/2008 traverse covering SyowaDome F route (black dotted line) (Fukui et al., 2010). Simulated curves are shown as blue solid line (Case 1), bule double dotted line (Case 2) and blue dotted line (Case 3). Each case corresponds to different super saturation functions shown in Table 3. Dots represent ice-core data of DF over the past $360 \mathrm{kyr}$ (red), Vostok over the past $250 \mathrm{kyr}$ (blue), and EDC over the past $140 \mathrm{kyr}$ (green). Here, $\delta \mathrm{D}$ and $d$ are corrected for $\delta^{18} \mathrm{O}_{\mathrm{sw}}$, see text for detail.

than the $10 \mathrm{~m}$-depth temperature of $-57.7^{\circ} \mathrm{C}$ (Motoyama et al., 2005) and 1-yr observations at $4 \mathrm{~m}$-height of $-54.8^{\circ} \mathrm{C}$ (Fujita and Abe, 2006).

The difficulties in simulating present-day $\delta$ values also reflect the difference between annual mean temperature and precipitation weighted temperature (e.g. Masson-Delmotte et al., 2011), and/or differences in prescribed surface airpressures. In fact, the air pressure at DF is the lowest among the coring sites due to its high elevation (3810 $\mathrm{m}$ a.s.1.), compared with the Vostok (3488 $\mathrm{m}$ a.s.l.) and EDC (3233 ma.s.1.). Lower air-pressure results in smaller distillation in the model, and thus produces higher simulated $\delta$ values.

We therefore have two options. Either we use a "realistic" DF temperature and perform regressions in an isotope range that is not sufficiently depleted when compared to the data; or we use colder than observed temperatures (and associated fractionation coefficients) to perform the regressions on the isotopic model results. Here, we explore the impacts of the second option of an "isotope fitted" procedure. We note that, as calibration targets, averaged isotope ratios are more reliable than Antarctic annual-mean temperature data due to the short instrumental records for instance at DF. 


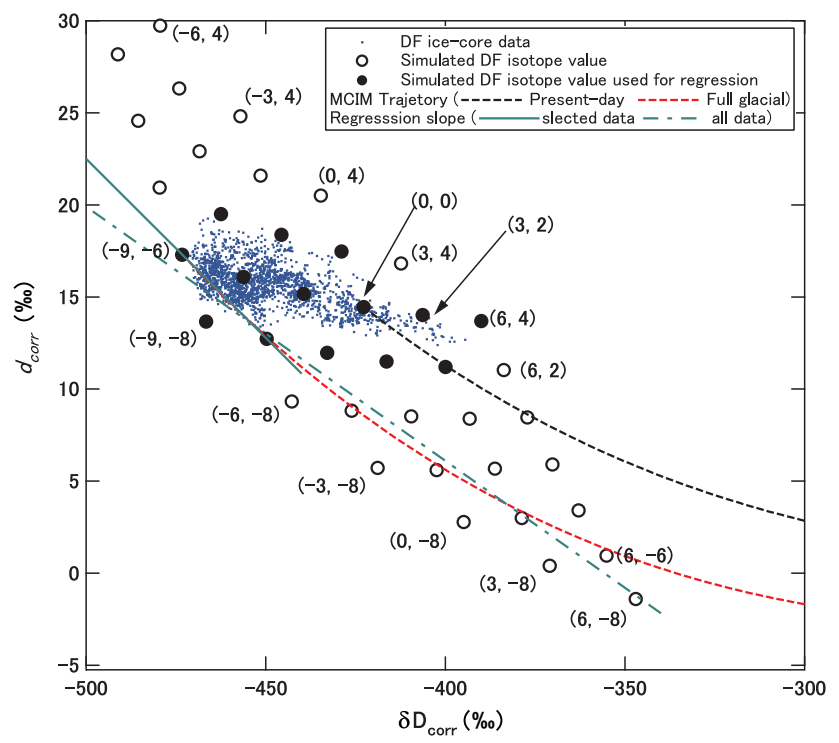

Fig. 5. Simulated $\delta \mathrm{D}$ and $d$ values in Antarctica. Trajectories of present-day (black dotted line) and glacial conditions (red dotted line) are shown. Each point (solid or open circles) represents the simulated snow isotope values at DF site under a specific site and source temperature setting, shown as $\left(\Delta T_{\text {site }}, \Delta T_{\text {source }}\right)$ in ${ }^{\circ} \mathrm{C}$. The DF ice core data (blue dot), and data used for regression analysis were shown as black solid circle. Linear regression $d / \delta \mathrm{D}$ slopes of a constant $\Delta T_{\text {source }}\left(=-6.0^{\circ} \mathrm{C}\right)$ obtained for the filled circles and all circles are shown as green solid and chain lines, respectively. Here, $\delta \mathrm{D}$ and $d$ are corrected for $\delta^{18} \mathrm{O}_{\mathrm{sw}}$, see text for detail.

The temperature range in Central East Antarctica and fractionation coefficients are extrapolated from values measured in laboratory experiments (with the coldest temperature of $-40.0^{\circ} \mathrm{C}$ and $-33.4{ }^{\circ} \mathrm{C}$ for deuterium (Merlivat and Nief, 1967) and oxygen-18 (Majoube, 1971b), respectively). These fractionation coefficients are thus not precisely known for very low temperatures and associated uncertainties should be kept in mind.

\section{Uncertainty on the sensitivity of $d$ to temperature}

\subsection{Sensitivity of $\boldsymbol{\beta}_{\text {site }}$ estimation}

In the multiple linear regressions (Eqs. 3 and 4), a major source of uncertainty lies in the coefficient of regression, $\beta_{\text {site }}\left(=\partial d / \partial \Delta T_{\text {site }}\right)$ which is related to the sensitivity of $d$ to $\Delta T_{\text {site. Table }} 1$ shows that $\beta_{\text {site }}$ values from previous studies are significantly different, ranging from $\sim 0.5$ (Cuffey and Vimeux, 2001; Stenni et al., 2001) to 1.2 (Salamatin et al., 2004). Note that some recent studies used new ${ }^{17} \mathrm{O}$ excess data to tune the MCIM and obtained larger $\beta_{\text {site }}$ values (Landais et al., 2009; Risi et al., 2010; Winkler et al., 2012). In principle, $\beta_{\text {site }}$ depends on the isotopic depletion as the temperature is almost linearly related to $\delta \mathrm{D}$. Figure 4 shows the $d-\delta \mathrm{D}$ slope increases with isotopic depletion and colder temperature ranges.

To test the $\beta_{\text {site }}$ sensitivity to temperature changes, the source and site temperatures at DF were changed without changing any tuning parameters (Table 2). We tuned the MCIM to simulate present-day snow isotope ratios ("Isotope fitted"), as described in Sect. 2.4. Two additional simulations were conducted to reproduce the present-day temperature $\left(-55^{\circ} \mathrm{C}\right)$. The first case used $T_{\text {source }}=18^{\circ} \mathrm{C}$ ("Temperature fitted 1") and the second case used $T_{\text {source }}$ as $11^{\circ} \mathrm{C}$ ("Temperature fitted 2"). The latter $T_{\text {source }}$ value was estimated using water tagging in a GCM simulation (Delaygue et al., 2000) and adopted for Vostok reconstruction (Vimeux et al., 2001). With these hypotheses on moisture source, the simulated isotope ratios were systematically higher than the values observed in the DF ice core. This prevents us from selecting the model results compatible with the DF ice core data (see Sect. 3.2). Instead, we performed sensitivity tests by varying $\Delta T_{\text {site }}$ and $\Delta T_{\text {source }}$ by $\pm 2{ }^{\circ} \mathrm{C}$, and performed multiple regressions on all the data.

Table 2 clearly shows that $\beta_{\text {site }}$ decreases as the simulated $\delta \mathrm{D}$ increases. Changes in $\beta_{\text {site }}$ are the largest $(\sim 130 \%)$ compared to the smaller changes in the other coefficients (from -20 to $30 \%$ ). This is explained by the increasing $d-\delta \mathrm{D}$ slope simulated in response to $\delta \mathrm{D}$ depletion. Figures 4 and 5 illustrate the non-stability of the linear slope between $d$ and $\delta \mathrm{D}$.

Note that the $\beta_{\text {site }}$ estimation (0.6) of "Temperature fitted 2" is comparable to the values $(0.5)$ used in previous ice core reconstructions. Thus, we conclude that most of the discrepancy found between previous studies can be explained by the choices of different methodologies: whether the model is tuned to reproduce the observed ice core isotope ratios (Salamatin et al., 2004), or is driven by realistic air-temperatures (Cuffey and Vimeux, 2001; Stenni et al., 2001). Our approach accounting for large slopes at cold temperatures allows us to explore this source of uncertainty on reconstructing site and source temperatures.

We tested the $\beta_{\text {site }}$ sensitivity to different supersaturation functions, corresponding to the upper and lower bounds compatible with present day data (Table 3, Fig. 4). These simulations were conducted with super saturation function $(\mathrm{Si})$, $1.020-0.0025 T$ and $1.020-0.0035 T$, respectively. In such a sensitivity test, it is difficult to reproduce correctly the present-day surface snow isotopic values , and we cannot select data for regression analysis based on ice core data (see Sect. 3.2). Consequently, we performed regression analysis by varying $\Delta T_{\text {site }}$ and $\Delta T_{\text {source }}$ by $\pm 2{ }^{\circ} \mathrm{C}$. The results show that the impact of different super-saturation functions on the value of $\beta_{\text {site }}$ is about $20 \%$, and that of the other parameters is marginal (Table 3 ). Therefore, the super saturation affects the $\beta_{\text {site }}$ parameters, but the impact is small compared with its sensitivity to different site and source temperatures conditions (Table 2). 
Table 1. Comparison of the tempearature inversion coefficients.

\begin{tabular}{|c|c|c|c|c|c|c|c|}
\hline Site & $\beta_{\text {site }}$ & $\beta_{\text {source }}$ & $\beta_{\mathrm{sw}}$ & $\gamma_{\text {site }}$ & $\gamma_{\text {source }}$ & $\gamma_{\mathrm{sw}}$ & Reference \\
\hline $\mathrm{DF}$ & 1.3 & 1.6 & - & 7.7 & 3.2 & - & This study \\
\hline Vostok $^{\mathrm{a}}$ & 0.5 & 1.3 & 2.8 & 7.1 & 3.7 & 4.8 & $\begin{array}{l}\text { Cuffey and Vimeux (2001); } \\
\text { Vimeux et al. (2002) }\end{array}$ \\
\hline Vostok $^{\mathrm{b}}$ & $0.9,1.2$ & $1.1,1.2$ & $3.0,2.9$ & $6.8,6.9$ & $2.8,3.6$ & $4.5,4.7$ & Salamantin (2004) \\
\hline Vostok $^{\mathrm{a}, \mathrm{c}}$ & 1.0 & 1.4 & 3 & & & & Landais et al. (2009) \\
\hline Vostok $^{\mathrm{c}}$ & 1.1 & 1.5 & - & - & - & - & Risi et al. (2010) \\
\hline Vostok & 1.4 & 1.6 & - & 7.7 & 3.1 & - & This study \\
\hline $\mathrm{EDC}^{\mathrm{a}}$ & 0.5 & 1.3 & 2.6 & 7.6 & 3.5 & 5.0 & $\begin{array}{l}\text { Stenni et al. (2001); } \\
\text { Masson-Delmotte et al. (2004) }\end{array}$ \\
\hline EDC & 0.5 & 1.3 & - & 7.6 & 3.6 & - & Stenni et al. (2003) \\
\hline EDC & 1.2 & 1.5 & - & 7.8 & 3.4 & - & This study \\
\hline East Antarctica ${ }^{\mathrm{a}, \mathrm{c}}$ & 1.29 to 2.04 & 1.31 to 1.5 & 3 & - & - & - & Winkler et al. (2012) \\
\hline
\end{tabular}

${ }^{\text {a }}$ Corrections for ocean isotope changes were estimated using $\beta_{\mathrm{sw}}$ and $\gamma_{\mathrm{sw}}: \Delta d=-\beta_{\text {site }} \Delta T_{\text {site }}+\beta_{\mathrm{source}} \Delta T_{\mathrm{source}}-\beta_{\mathrm{sw}} \Delta \delta^{18} \mathrm{O}_{\mathrm{sw}}$, and $\Delta \delta \mathrm{D}=$

$\gamma_{\text {site }} \Delta T_{\text {site }}-\gamma_{\text {source }} \Delta T_{\text {source }}+\gamma_{\mathrm{sw}} \Delta \delta^{18} \mathrm{O}_{\mathrm{sw}}$. See the Sect. 2.3 for detail. ${ }^{\mathrm{b}}$ Condensation temperature at precipitation deposition site $\left(\Delta T_{\mathrm{c}}\right)$ used in original paper was converted to tempearature at ground level $\left(\Delta T_{\text {site }}\right)$ using a linear relation $\Delta T_{\mathrm{c}}=0.67 \Delta T_{\text {site }}$ (Jouzel and Merlivat, 1984). Thus, the $d / T_{\mathrm{c}}$ slopes (1.7 and 1.4 for 2 different trajectories) correspond to the values of 1.2 and 0.9 for $\beta_{\text {site }}{ }^{\mathrm{c}}$ Variations of relative humidity was estimated as an independent parameter.

Table 2. Test of $\beta_{\text {site }}$ sensitivity to the source and site temperatures.

\begin{tabular}{|c|c|c|c|c|c|c|c|c|c|}
\hline \multirow[b]{2}{*}{ Tuning strategy } & \multicolumn{3}{|c|}{ Simulated DF isotope ratio $(\%)$} & \multicolumn{2}{|c|}{ Temperature $\left({ }^{\circ} \mathrm{C}\right)$} & \multicolumn{4}{|c|}{ Sensitivity coefficient $\left(\% o{ }^{\circ} \mathrm{C}\right)$} \\
\hline & $\delta \mathrm{D}$ & $\delta^{18} \mathrm{O}$ & $d$ & DF site & Source & $\beta_{\text {site }}$ & $\beta_{\text {source }}$ & $\gamma_{\text {site }}$ & $\gamma_{\text {source }}$ \\
\hline Isotope fitted & -422.7 & -54.6 & 14.5 & -61.0 & 18.0 & 1.3 & 1.6 & 7.7 & 3.2 \\
\hline Temperature fitted 1 & -377.1 & -48.2 & 8.5 & -55.0 & 18.0 & 0.8 & 1.3 & 7.6 & 3.4 \\
\hline Temperature fitted 2 & -351.1 & -43.9 & -0.2 & -55.0 & 11.0 & 0.6 & 1.2 & 7.9 & 4.1 \\
\hline
\end{tabular}

\subsection{Data selection for regressions}

Another methodology that affects the $\beta_{\text {site }}$ value is the data selection criteria used for establishing the multiple linear regressions coefficients. In previous studies, the regression analyses were performed on the simulated $\delta$ values in response to a wide range of randomly changed climate conditions ( $\left.\Delta T_{\text {site }}, \Delta T_{\text {source }}\right)$ (e.g. Masson-Delmotte et al., 2004). The large range of results obtained for DF with this approach is illustrated in Fig. 5 as open circles.

In contrast, we propose to restrict the range of site and source conditions for which the modeled isotopic results are consistent with the glacial-interglacial ice core data. Note that our model results account for sea water isotopic composition corrections; this is a marginal source of uncertainty in the model-data comparison. We therefore selected a subset of the modelled isotope values (and corresponding $\Delta T_{\text {site }}$ and $\Delta T_{\text {source }}$ ) displayed as black circles in Fig. 5, and performed the multiple linear regression analysis on this dataset. We illustrate in Fig. 5 the importance of this data selection for the $d-\delta \mathrm{D}$ slopes, which increase with isotopic depletion and temperature ranges. Generally, excluding higher $\delta \mathrm{D}$ data results in larger $d-\delta \mathrm{D}$ slope and thus larger $\beta_{\text {site }}$ coefficient. Our approach results in a larger $\beta_{\text {site }}$ coefficient compared to the previous approaches.
These results suggest that our methodology, using the MCIM model with deliberately cold conditions and selected data, should be seen as an upper end approach for the $\beta_{\text {site }}$ coefficient, compared to previous approaches which did not sufficiently account for the large slope at cold temperatures.

\subsection{Different sensitivity coefficients}

The isotope inversion was performed to retrieve the $\Delta T_{\text {site }}$ and $\Delta T_{\text {source }}$ information using the method described above ( $\mathrm{Si}=1.020-0.003 T$, and present $T_{\text {site }}$ and simulated $\delta$ values are shown as isotope fitted in Table 1). The linear relations obtained for the DF ice core are

$$
\begin{aligned}
& \Delta \delta D_{\text {corr }}=7.7 \Delta T_{\text {site }}-3.2 \Delta T_{\text {source }} \\
& \left(R^{2}=0.999, n=14, p<0.001\right) \\
& \Delta d_{\text {corr }}=-1.3 \Delta T_{\text {site }}+1.6 \Delta T_{\text {source }} \\
& \left(R^{2}=0.989, n=14, p<0.001\right)
\end{aligned}
$$

The linear correlations are strong, thus the statistical uncertainty of each coefficient due to multiple regression analysis is very small $(0.03$ to 0.05$)$. The uncertainty caused by the data selection for the regression analysis (Sect. 3.2) is also small. In fact, if we remove several ( 1 to 5$)$ points located around the "corner" of data subset (Fig. 5), the uncertainties 
Table 3. Test of $\beta_{\text {site }}$ sensitivity to the super saturation function.

\begin{tabular}{|c|c|c|c|c|c|c|c|c|c|}
\hline \multirow[b]{2}{*}{ Super saturation function $\left(S_{i}\right)$} & \multicolumn{3}{|c|}{ Simulated DF isotope ratio(\%o) } & \multicolumn{2}{|c|}{ Temperature $\left({ }^{\circ} \mathrm{C}\right)$} & \multicolumn{4}{|c|}{ Coefficient $\left(\% o /{ }^{\circ} \mathrm{C}\right)$} \\
\hline & $\delta \mathrm{D}$ & $\delta^{18} \mathrm{O}$ & $d$ & Site & Source & $\beta_{\text {site }}$ & $\beta_{\text {source }}$ & $\gamma_{\text {site }}$ & $\gamma_{\text {source }}$ \\
\hline $1.020-0.0030 T$ (case 1$)$ & -422.7 & -54.6 & 14.5 & -61.0 & 18.0 & 1.3 & 1.6 & 7.7 & 3.2 \\
\hline $1.020-0.0025 T$ (case 2) & -403.6 & -52.2 & 13.9 & -58.0 & 18.0 & 1.2 & 1.4 & 7.7 & 3.3 \\
\hline $1.020-0.0035 T$ (case 3$)$ & -441.3 & -57.0 & 14.3 & -64.0 & 18.0 & 1.1 & 1.6 & 7.5 & 3.0 \\
\hline
\end{tabular}

of the linear coefficients are 0.01 to 0.04 . Such statistical regression error analysis, however, does not represent the total uncertainties on the estimated $\Delta T_{\text {site }}$ and $\Delta T_{\text {source. It does not }}$ account for uncertainties on MCIM parameterization tunings (e.g. supersaturation), and on climate parameters not taken into account (precipitation intermittency, inversion strength, changes in wind speed and/or relative humidity). For example, Winkler et al. (2012) show that the $\beta_{\text {site }}$ depends on the tuning of supersaturation, and an error range was estimated as 1.29 to 2.04 .

We have also applied the exact same methodology for EDC and Vostok, using the same tuning of MCIM and performing the linear analyses on the range of model outputs consistent with each ice core isotopic dataset. Table $1 \mathrm{com}-$ pares our results with previous regressions. Among four coefficients in the equations, only $\beta_{\text {site }}$ is significantly different from previous estimate, which is now 2.5 times larger than previous one $(\sim 0.5)$. As discussed in Sects. 3.1 and 3.2, differences found in $\beta_{\text {site }}$ between previous studies can be explained by the different methodologies: whether the model is tuned to reproduce the isotope ratios or air-temperature.

The value of $\beta_{\text {site }}$, which seems high for East Antarctica sites, is actually very dependent on the $d$ definitions and on the range of temperatures studied. To understand the influence of the historical linear definition of $d$ on the $\beta_{\text {site, }}$, we tested a logarithmic definition of $d$ (see Appendix A for detail). The results confirm that the value of $\beta_{\text {site }}$ significantly depends on the definition of $d$. A logarithm $d$ definition can remove the influence of $\Delta T_{\text {site }}$ on $d$ spatial variations, and thus significantly reduce the value of $\beta_{\text {site. }}$. But this new definition does not change the temperature reconstructions, because $\beta_{\text {site }}$ acts as a correction factor for the empirically defined $d$ parameter.

\section{Reconstructed $\Delta T_{\text {source }}$ and $\Delta T_{\text {site }}$}

\section{1 $\Delta T_{\text {source }}$ and $\Delta T_{\text {site }}$ of Dome $F$}

The new coefficients obtained in this study (Eqs. 5 and 6) were applied to the DF ice core data to estimate past variations in $\Delta T_{\text {source }}$ and $\Delta T_{\text {site }}$ (Fig. 6). The new $\Delta T_{\text {source }}$ ranges from $-5.9^{\circ} \mathrm{C}$ to $2.9^{\circ} \mathrm{C}$ over the past $360 \mathrm{kyr}$. The record shows maxima of $\Delta T_{\text {source }}$ occurring during Marine Isotope Stage (MIS) 5e and MIS 9e with values respectively

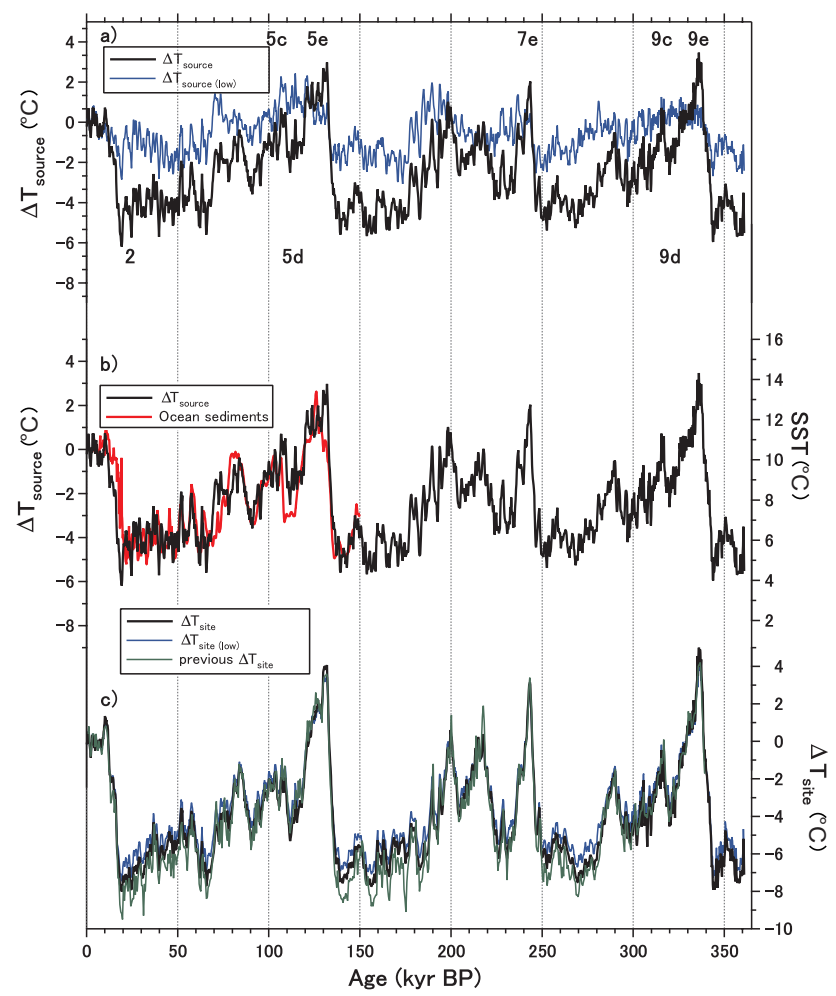

Fig. 6. Different $\Delta T_{\text {source }}$ and $\Delta T_{\text {site }}$ of DF and a stacked SST records. (a) Black line represents the $\Delta T_{\text {source }}$ record of DF core based on the coefficients $\left(\beta_{\text {site }}=1.3\right.$ ) obtained by isotope-fitting (this study). Blue line represents the $\Delta T_{\text {source }}^{\text {low record of DF core }}$ based on the coefficients ( $\left.\beta_{\text {site }}=0.5\right)$ used for Vostok reconstruction (temperature-fitting) (Cuffey and Vimeux, 2001; Vimeux et al., 2002). Numbers indicate Marine Isotope Stages. (b) Black line is the $\Delta T_{\text {source }}$ of DF core, same as (a), but with a stacked southern SST record of ocean sediments (Barrows et al., 2007) (red line). (c) The $\Delta T_{\text {site }}$ record based on the coefficients of this study (black line), $\Delta T_{\text {site }}^{\text {low }}$ (blue line), and previous $\Delta T_{\text {site }}$ reconstruction of DF core (temperature-fitting) (Kawamura et al., 2007).

$2.6 \pm 0.3^{\circ} \mathrm{C}$ and $2.9 \pm 0.3{ }^{\circ} \mathrm{C}$ higher than present. A glacial minimum at $19 \mathrm{kyr} \mathrm{BP}$ is $-5.9 \pm 0.3^{\circ} \mathrm{C}$. Here, temperatures are based on the average and $\pm 1 \sigma$ of 1 kyr duration around the maximum or minimum point. This $\Delta T_{\text {source }}$ reconstruction remains high when $\Delta T_{\text {site }}$ and $\delta \mathrm{D}$ drop during glacial inceptions, linked with high $d$ values during the onset of glaciations. The DF $\Delta T_{\text {site }}$ derived from the new coefficients ranges 
from $-7.8 \pm 0.2^{\circ} \mathrm{C}$ to $4.8 \pm 0.5^{\circ} \mathrm{C}$ over the past $360 \mathrm{kyr}$. Maximum $\Delta T_{\text {site }}$ occur during MIS 9e, with temperature $4.8 \pm 0.5^{\circ} \mathrm{C}$ warmer than that of present-day average.

In order to show the importance of the value of $\beta_{\text {site, }}$, other $\Delta T_{\text {source }}$ and $\Delta T_{\text {site }}$ records which were obtained using the smaller values of $\beta_{\text {site }}(0.5)$ and other coefficients used in Cuffey and Vimeux (2001) (Table 1) are shown in Fig. 6a. For clarity, we labeled this $\Delta T_{\text {source }}$ and $\Delta T_{\text {site }}$ records based on the smaller $\beta_{\text {site }}$ coefficient as $\Delta T_{\text {source }}^{\text {low }}$ and $\Delta T_{\text {site }}^{\text {low }}$, respectively. Two major differences are identified for the source temperature records. First, the glacial-interglacial amplitude of the new $\Delta T_{\text {source }}$ is approximately twice larger than that of $\Delta T_{\text {source. }}^{\text {low }}$. Second, the timing of the interglacialglacial inception maxima is strongly affected: small $\beta_{\text {site }}$ coefficients induce a maximum $\Delta T_{\text {source }}^{\text {low }}$ at the onset of glaciations (MIS 5d), while large $\beta_{\text {site }}$ coefficients place $\Delta T_{\text {source }}$ maxima in phase with Antarctic warmth (MIS 5e). With the exception of glacial inceptions, the new $\Delta T_{\text {source }}$ reconstruction is also much more similar to $\Delta T_{\text {site. Note that a very }}$ similar result is obtained by changing only the value of $\beta_{\text {site }}$ from 1.3 (this study) to 0.5 (smaller value) because among four coefficients, only the $\beta_{\text {site }}$ is significantly different from previous estimates. Figure $6 \mathrm{a}$, therefore, shows the fact that the $\beta_{\text {site }}$ coefficient directly affects the glacial-interglacial magnitude of $\Delta T_{\text {source }}$.

In contrast to the sensitivity of $\Delta T_{\text {source }}$ to the uncertainties in regression coefficients, the $\Delta T_{\text {site }}$ shows much less sensitivity (Fig. 6c). Indeed, the difference between $\Delta T_{\text {site }}$ and $\Delta T_{\text {site }}^{\text {low }}$ is $\sim 0.6^{\circ} \mathrm{C}$, which is within typical error $(-10-30 \%)$ of temperature estimations (Jouzel et al., 2003). Published DF $\Delta T_{\text {site }}$ (which corresponds to $\Delta T_{\text {site }}^{\text {low }}$ ) estimates MIS 9e to be warmer than the present by $4.0 \pm 0.3^{\circ} \mathrm{C}$ (Kawamura et al., 2007) (Fig. 6c). Our revised estimate of $4.8 \pm 0.5^{\circ} \mathrm{C}$ is slightly warmer than previous MIS 9e $\Delta T_{\text {site }}$ values, but it remains within the uncertainty range. For MIS $5 \mathrm{e}$, previous and our DF $\Delta T_{\text {site }}$ estimates are $3.5 \pm 0.1{ }^{\circ} \mathrm{C}$ and $3.7 \pm 0.4{ }^{\circ} \mathrm{C}$, respectively. The $\Delta T_{\text {site }}$ records from six Antarctic ice cores also show similar degree of warming during interglacial periods (Masson-Delmotte et al., 2011). A GCM study, based on increased $\mathrm{CO}_{2}$ projections, however, suggested that MIS 5e isotope temperature may have been 6 to $10^{\circ} \mathrm{C}$ warmer than present day (Sime et al., 2009). This estimate is significantly larger than any of our reconstructions. Thus, these results suggest that moisture source effects cannot explain the model-data discrepancy.

\subsection{Comparison with the other cores}

The methodology used to obtain $\Delta T_{\text {site }}$ and $\Delta T_{\text {source }}$ at DF is also used on Vostok and EDC data (Table 1). Figure 7 shows the $\Delta T_{\text {source }}, \Delta T_{\text {site }}$, and the temperature gradient records.

The glacial-interglacial changes in $\Delta T_{\text {source }}$ are significantly larger than the estimates using previous MCIM tuning. For Vostok, the new $\Delta T_{\text {source }}$ decreases to about $-6.0 \pm 0.1{ }^{\circ} \mathrm{C}$ around $19 \mathrm{kyr} \mathrm{BP}$ (temperatures are based on

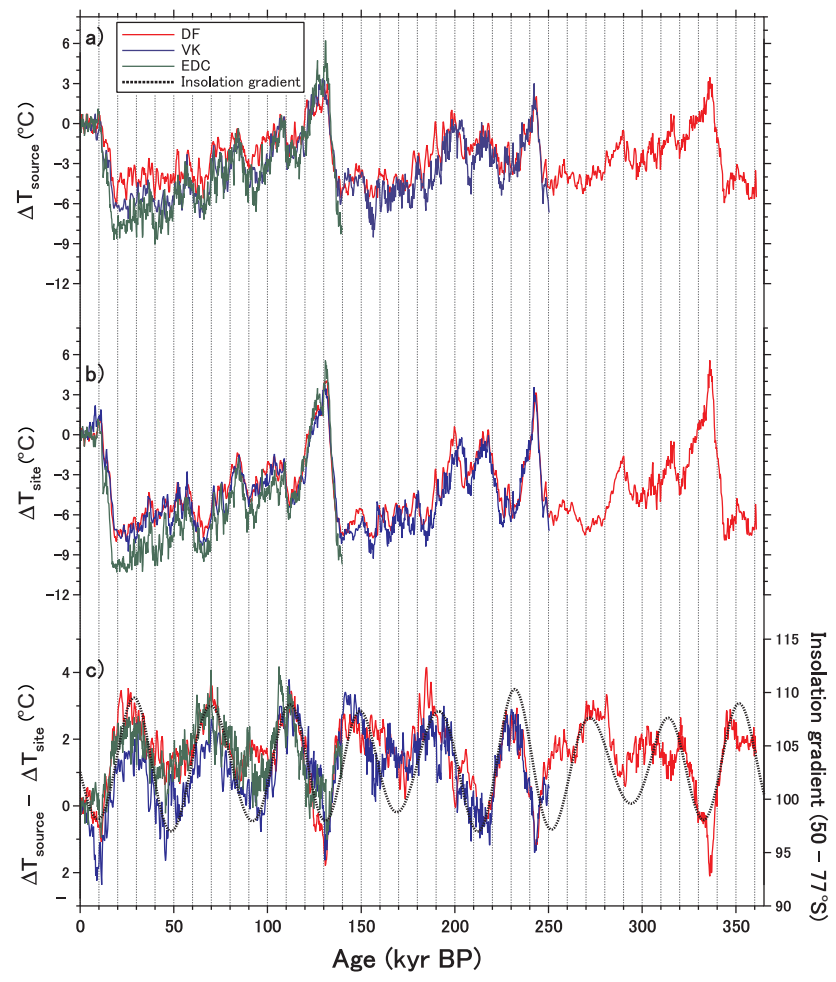

Fig. 7. The $\Delta T_{\text {site }}, \Delta T_{\text {source }}$, and the temperature gradient derived from the three cores. Temperature records reconstructed from the DF (red line), Vostok (blue line), and EDC (green line) cores using the isotope-fitting method. (a) $\Delta T_{\text {source }}$, (b) $\Delta T_{\text {site }}$, (c) Temperature gradient $\left(=\Delta T_{\text {source }}-\Delta T_{\text {site }}\right)$ and annual mean insolation gradient between 50 and $77^{\circ} \mathrm{S}\left(\mathrm{Wm}^{-2}\right.$, black dotted line).

the $1 \mathrm{kyr}$ average $\pm 1 \sigma$ ), which is cooler than previous estimates of $\sim-4^{\circ} \mathrm{C}$ (Vimeux et al., 2002). For the EDC, the $\Delta T_{\text {source }}$ decrease to $-8.1 \pm 0.3^{\circ} \mathrm{C}$ at $19 \mathrm{kyr} \mathrm{BP}$, which is much lower than the previous estimation of -3 to $-4^{\circ} \mathrm{C}$ (Stenni et al., 2010). This large EDC $\Delta T_{\text {source variation re- }}$ sults from $\beta_{\text {site }}$ value, which results in a larger proportion of $\delta \mathrm{D}$ added to the raw $d$ record.

The glacial-interglacial changes in $\Delta T_{\text {site }}$ are close to the previous estimations. The Vostok $\Delta T_{\text {site }}$ estimations based on this study decreased to about $-7.1^{\circ} \mathrm{C}$ at $19 \mathrm{kyr} \mathrm{BP}$ and reached the minimum at $-7.8^{\circ} \mathrm{C}$ at $21.7 \mathrm{kyr} \mathrm{BP}$. These values are almost the same as the previous estimates (Vimeux et al., 2002). For the EDC, our $\Delta T_{\text {site }}$ estimate decreases to about $-9.9 \pm 0.2^{\circ} \mathrm{C}$ at $19 \mathrm{kyr} \mathrm{BP}$, slightly lower than the previous estimate of -8 to $-9^{\circ} \mathrm{C}$ at $20 \mathrm{kyr}$ BP without accounting for elevation corrections (Stenni et al., 2003, 2010). The lower $\Delta T_{\text {site }}$ results from combination of relatively larger variation in $\delta \mathrm{D}$ and larger $\gamma_{\text {site }}$ values. In summary, as for DF case, the new $\Delta T_{\text {site }}$ estimations of Vostok and EDC cores are consistent with the previous estimates within typical error $(-10-30 \%)$ (Jouzel et al., 2003). Interestingly, at glacial inceptions, all the $\Delta T_{\text {site }}$ records show warmer values than classical $\delta \mathrm{D}$-temperature estimates, and thus the co-variation 
of $\Delta T_{\text {site }}$ and $\mathrm{CO}_{2}$ found in Vostok core (Cuffey and Vimeux, 2001) is generally supported.

Our reconstructed $\Delta T_{\text {site }}$ and $\Delta T_{\text {source }}$ are lower at EDC than other east Antarctic stations (Fig. 7). This is consistent with a larger $\delta$ D depletion at EDC. A GCM simulation suggests that differences in $\delta$ can be explained primarily by variations in the palaeothermometer gradient (i.e. $\partial \delta / \partial T$ ), rather than in temperature (Sime et al., 2009). Note that their study does not include correction for moisture source, but used either $\delta \mathrm{D}$ or $\delta^{18} \mathrm{O}$ value. Our study revealed that the moisture source correction based on $d$ value does not explain the isotopic differences, because our $\Delta T_{\text {site }}$ estimate at EDC is still colder than the others.

The temperature gradients $\left(\Delta T_{\text {source }}-\Delta T_{\text {site }}\right)$ of DF, EDC and Vostok show a strong 40-kyr cycle (Fig. 7). Such marked 40-kyr periodicity has not been found in previous reconstructions of temperature gradient at Vostok (Vimeux et al., 2002) and EDC (Stenni et al., 2010) as the gradient was strongly correlated with $\Delta T_{\text {site }}\left(r^{2}=0.9\right)$ (Stenni et al., 2010). The glacial-interglacial variations of the gradient of this study ranges from -2 to $4{ }^{\circ} \mathrm{C}$. These variations are smaller than the previous by $\sim 2$ to $3{ }^{\circ} \mathrm{C}(\sim 40 \%$ smaller $)$. The amplitude of temperature gradient ranged from -3 to $6^{\circ} \mathrm{C}$ at Vostok (Vimeux et al., 2002), and -2 to $6^{\circ} \mathrm{C}$ at EDC (Stenni et al., 2010).

\subsection{Comparison with SST records from ocean sediments}

Which (low versus high coefficient) approach is most consistent with independent information? Here, we use sea surface temperature (SST) estimates obtained from ocean proxy records, and compare these to our reconstructed $\Delta T_{\text {source. }}$. We are aware that different marine proxies can lead to significant uncertainties in reconstructions, which can also have seasonal biases (e.g. MARGO project members, 2009). The recent synthesis of LGM SST data depicts a latitudinal temperature gradient in the Southern Hemisphere oceans. Backward trajectory models suggest that the present-day main moisture source for DF is located around the $40-70^{\circ} \mathrm{S}$ ocean (Reijmer et al., 2002; Sodemann and Stohl, 2009). In the $42.5-52.5^{\circ} \mathrm{S}$ latitudinal band, the LGM minus present-day anomaly is $-3.8^{\circ} \mathrm{C}$ (MARGO Project Members, 2009). Figure $6 \mathrm{~b}$ shows a stacked Southern Ocean mid-latitude SST record (Barrows et al., 2007) that was made by combining the ocean sediment records from the MD97-2120 $\left(45^{\circ} 32^{\prime} \mathrm{S}\right.$, $174^{\circ} 56^{\prime} \mathrm{E}$ ) from east of New Zealand (Pahnke and Sachs, 2006) and MD88-770 $\left(46^{\circ} 01^{\prime} \mathrm{S}, 96^{\circ} 27^{\prime} \mathrm{E}\right)$ from the Indian Ocean (Labeyrie et al., 1996). The stacked SST record shows a relatively large SST shift $\left(\sim 5^{\circ} \mathrm{C}\right)$ during Termination I. Another sediment core (MD07-3076) retrieved in the Atlantic sector of the Southern Ocean $\left(44^{\circ} 09^{\prime} \mathrm{S}\right.$, $14^{\circ} 13^{\prime} \mathrm{W}$ ) shows a glacial-interglacial temperature change of $\sim 7^{\circ} \mathrm{C}$ both during Termination I (Skinner et al., 2010) and Termination V (Vázquez Riveiros et al., 2010).
Our $\Delta T_{\text {source }}$ variation based on isotope-fitting is therefore only compatible with the largest SST amplitude estimates. However, the moisture source likely moves between glacial and interglacial periods, as suggested by water tagging in atmospheric models (Delaygue et al., 2000) or abrupt shifts of $d$ (Masson-Delmotte et al., 2010a). During glacial periods, northward shifts of the mean evaporation locations are expected to compensate the impact of SST cooling into $\Delta T_{\text {source. }}$ While associated with uncertainties on the actual moisture sources and the proxy-based SST reconstructions, this comparison suggests that our large $\Delta T_{\text {source }}$ reconstruction is at the upper limit of compatibility with SST data. Note that the $\Delta T_{\text {source }}$ estimated using MCIM indicates ocean surface temperature averaged (vapor amount weighted) by different moisture sources. Thus, separating the source-areas requires additional information (i.e. chemical composition, backward trajectory analysis, and general circulation model, etc.). There are also several limitations for the $\Delta T_{\text {source }}$ reconstruction caused by uncertainties on supersaturation and precipitation intermittency in different past climate conditions.

\subsection{Obliquity and deuterium-excess}

A strong 41-kyr Earth's obliquity periodicity is detected in many paleoclimatic SST records, in both hemispheres (Cortijo et al., 1999; Sachs et al., 2001) including ice cores (Jouzel et al., 2007). Based on this paleoclimatic evidence, obliquity was suggested to be a key driver of glacialinterglacial dynamics (Vimeux et al., 1999, 2001; Khodri et al., 2001; Raymo and Nisancioglu, 2003; Loutre et al., 2004; Huybers and Wunsch, 2005; Lee and Poulsen, 2008; Davis and Brewer, 2009).

The raw $d$ record from Antarctic ice cores also shows a strong 41-kyr obliquity periodicity (Stenni et al., 2001, 2003, 2010; Vimeux et al., 1999; Uemura et al., 2004). Previous studies suggested that the obliquity component of the Vostok $d$ record could be related to the contrasting impact of obliquity on annual mean insolation and temperature at low and high latitudes (affecting SST), amplified by changes in the moisture transport induced by the annual insolation gradient between low and high latitudes (Vimeux et al., 1999; Loutre et al., 2004). In previous reconstructions, $\Delta T_{\text {source }}^{\text {low }}$ was similar to the raw deuterium excess signals and showed a large obliquity imprint.

Interestingly, $\delta \mathrm{D}$ and $d$ are anti-correlated in the $40-\mathrm{kyr}$ band (Fig. 8). As a result, small differences in $\beta_{\text {site }}$ have large impacts on the obliquity signal in $\Delta T_{\text {source }}$. Spectral analysis shows that our new $\Delta T_{\text {source }}$ reconstruction indeed has a weak obliquity signal (Fig. 9). It cannot therefore be ruled out that the strong obliquity signal found in the raw $d$ records of DF and Vostok cores is an artifact of site temperature. This does not apply to EDC where the obliquity imprint in the raw $d$ is less clear. 


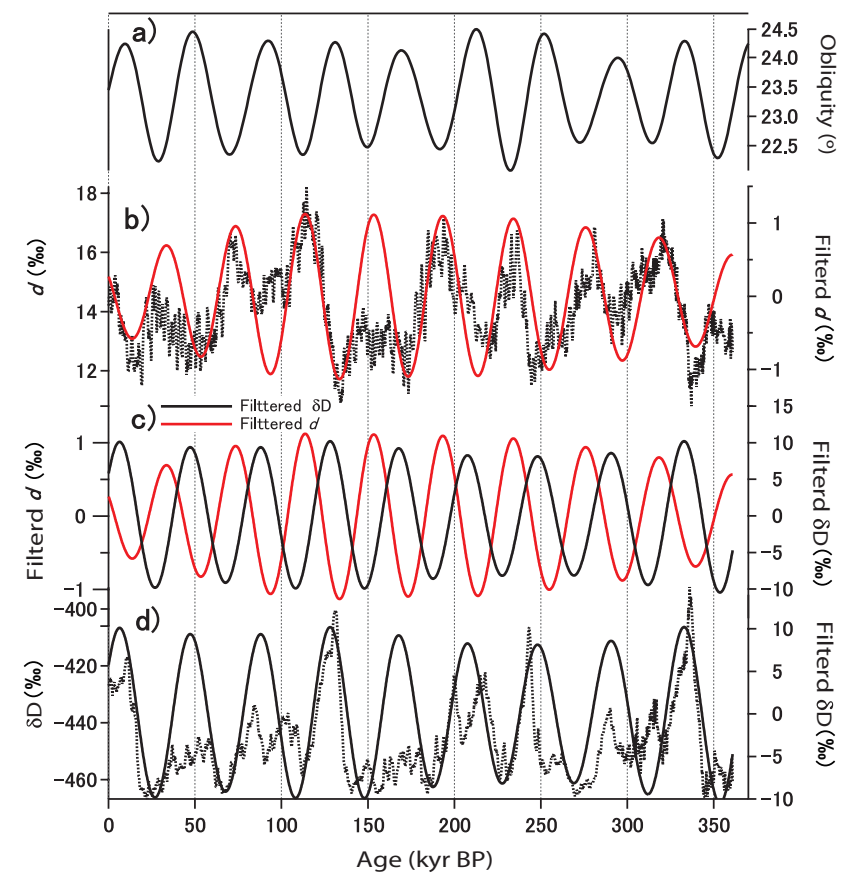

Fig. 8. Obliquity components of the DF isotope records. (a) Earth's obliquity, (b) the raw $d$ record of DF (black dotted line) and its filtered signal (red solid line). The filtered obliquity component was obtained by Gaussian filters with the Analyseries program (Paillard et al., 1996). A band-pass filter in the obliquity band ( $f=$ $0.025 \pm 0.005$ ) was calculated (red solid line). (c) Filtered components in the DF $d$ (red solid line) and $\delta \mathrm{D}$ (black solid line), (d) the $\delta \mathrm{D}$ (black dotted line) record of DF and its filtered signal (black solid line).

As a result of our new reconstruction, spectral properties of our temperature gradient $\left(\Delta T_{\text {source }}-\Delta T_{\text {site }}\right)$ from DF, Vostok and EDC cores appears mainly modulated by obliquity (Fig. 9) and without $100 \mathrm{kyr}$ cycles. A recent modeling study (Antico et al., 2010) supports a large control of obliquity on latitudinal moisture transport.

Compared with $\delta \mathrm{D}$, the strong imprint of obliquity is reduced in our $\Delta T_{\text {site }}$ reconstruction (Fig. 9), suggesting that it can be partly affected by moisture origin effects. The obliquity signal, however, remains in $\Delta T_{\text {site }}$. Thus, the moisture source effect cannot fully explains the fact that climate models display a negligible impact of obliquity on the simulated annual mean Antarctic temperature, suggesting that it may result from model biases, such as a lack of austral sea ice in control simulations (Masson-Delmotte et al., 2010b).

Furthermore, our synchronized age scale is based on the imprint of precession on $\mathrm{DF} \mathrm{O}_{2} / \mathrm{N}_{2}$ and is independent from orbital properties of the stable isotope records. In our high $\beta_{\text {site }}$ case, the site-source temperature gradient mainly exhibits obliquity periodicities, which is a requested characteristic for orbital tuning. Cross spectrum analysis shows that the mean lag of this reconstructed temperature gradient behind the annual mean insolation gradient (Fig. 7c; which is an antiphase of obliquity) is $1.3 \pm 0.4 \mathrm{kyr}$. The gradients of EDC and Vostok also lag the obliquity by $1.9 \pm 0.7$ and $0.9 \pm 0.5 \mathrm{kyr}$, respectively. This differs from the observed 5 kyr lag between EDC $\delta$ D and obliquity (Jouzel et al., 2007). The processes responsible for the observed lags remain elusive, and likely involved the interplay between ice sheets and ocean circulation. Further investigations of the mechanisms linking obliquity and site-source temperature gradient are required, in order to use such information for orbital dating of ice cores. It will provide independent evidence to test the length of MIS 11, in which the accuracy of the EDC3 age scale (Parrenin et al., 2007) was questioned (MassonDelmotte et al., 2010b; Pol et al., 2011).

\section{Conclusions and perspective}

We obtained a new $d$ record from DF ice core spanning the past $360000 \mathrm{yr}$ and compared this with records from Vostok and EDC ice cores. To interpret the $d$ and $\delta \mathrm{D}$ records as $\Delta T_{\text {source }}$ and $\Delta T_{\text {site }}$ information, we used an isotopic inversion methodology based on the MCIM model as previously performed by Vimeux et al. (2002); Stenni et al. (2001) on the Vostok and EDC ice cores respectively. A major source of uncertainty lies in the coefficient of regression, $\beta_{\text {site }}$ which is related to the sensitivity of $d$ to $\Delta T_{\text {site }}$. We showed that different ranges of temperature and selections of isotopic model outputs increase the value of $\beta_{\text {site }}$ by a factor of two. The results suggests that the differences of $\beta_{\text {site }}$ from previous studies are due to the isotopic model tuning for the present-day, and the $\delta \mathrm{D}$ ranges selected for regression analyses. We have shown that the $\beta_{\text {site }}$ depends on the range of temperature or isotopic depletion used.

For the first time, we applied the exact same temperature inversion methodology to the three Antarctica ice cores data sets (DF, Vostok, and EDC). All $\Delta T_{\text {source }}$ records were sensitive to the inversion method, with our new approach (isotope-

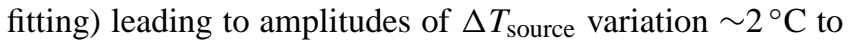
$4{ }^{\circ} \mathrm{C}$ larger compared to the previous estimations. For DF, the $\Delta T_{\text {source }}$ estimates yields values between $-5.9^{\circ} \mathrm{C}$ and $2.9^{\circ} \mathrm{C}$ over the past $360 \mathrm{kyr}$, Comparisons with proxy-based SST records suggest that our large $\Delta T_{\text {source }}$ reconstruction is at the upper limit of compatibility with SST data. In contrast to the significant modification in $\Delta T_{\text {source, }}$, the $\Delta T_{\text {site }}$ records were not modified significantly and therefore appear robust. The differences between the current and previous studies are within published uncertainty $(-10-30 \%)$ of $\Delta T_{\text {site }}$ estimations. The new $\Delta T_{\text {source }}$ estimates showed only weak $41-\mathrm{kyr}$ obliquity periodicity, but the obliquity signal was found in the temperature gradient $\left(\Delta T_{\text {source }}-\Delta T_{\text {site }}\right)$. The temperature gradient records of the three cores show a systematic anticorrelation with obliquity, providing new evidence for the importance of the Earth's obliquity as a driver of water cycle and climate dynamics. Such properties offer the perspective 

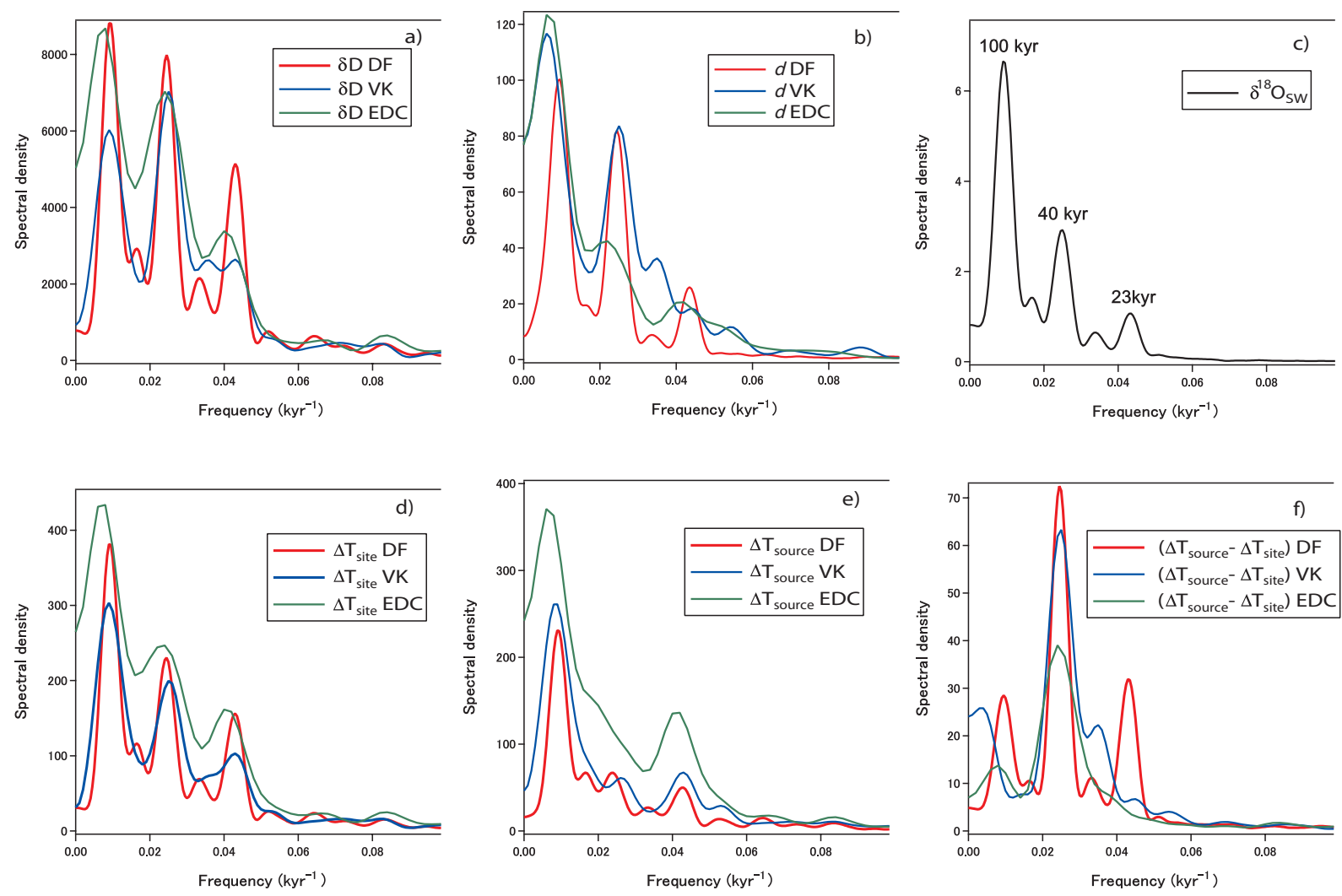

Fig. 9. Power spectra of DF core isotope records. Power spectra of DF (red), Vostok (blue), and EDC (green); (a) $\delta$ D, (b) $d$, (c) Ocean isotope

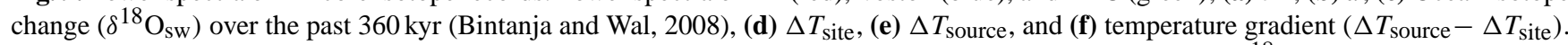
Spectral analysis is performed using Blackman-Tukey analysis with $50 \%$ of series lag (for DF, Vostok, and $\delta^{18} \mathrm{O}_{\mathrm{sw}}$ ) and $70 \%$ (for EDC) with the Analyseries software (Paillard et al., 1996).

of using this obliquity imprint as a synchronization tool for dating ice cores.

The isotope inversion method involves simplification, and the procedure is challenging, in particular in Antarctica where isotope ratios are extremely depleted. Analyzing $d$ at an event basis in modern condensing vapor and precipitation is useful when combined with moisture tracking analysis (Sodemann and Stohl, 2009) and isotopic modeling, to identify hypotheses and parameterizations in distillation models regarding the controls of $d$. Our results depend on the prescribed fractionation coefficients. It is also necessarily to improve the quantification of isotopic fractionation coefficients of under kinetic conditon (Luz et al., 2009; Uemura et al., 2010b) and equilibrium condition at very low temperatures (Ellehoj et al., 2012). Triple isotope ratios of oxygen (i.e. ${ }^{17} \mathrm{O}$-excess) in water molecules (Landais et al., 2008, 2011; Luz and Barkan, 2010; Winkler et al., 2012) would also provide independent evidence for moisture source imprint on isotopically depleted snow. Finally, extensive field observation of $d$ and ${ }^{17} \mathrm{O}$-excess in clouds over Antarctica may provide better constraints on supersaturation function, and will allow to improve our understanding of the mechanism underlying the changes in $d$ and ${ }^{17} \mathrm{O}$ excess.

\section{Appendix A}

\section{Logarithmic definition of $\boldsymbol{d}$ and meaning of $\beta_{\text {site }}$}

The interplay of artifacts caused by the empirical $d$ definition and by physical kinetic processes (evaporation and snow formation) restricts precise physical understanding of meaning to the value of two coefficients ( $\beta_{\text {site }}$ and $\left.\beta_{\text {source }}\right)$ in Eq. (4). The empirical definition (i.e. the constant slope of 8) of $d$ itself induces changes in $d$ because any process that does not follow the $\delta \mathrm{D} / \delta^{18} \mathrm{O}$ slope of 8 alters the $d$ value. Indeed the $\delta \mathrm{D} / \delta^{18} \mathrm{O}$ slope can deviate from the mean value of 8 because of the combination of the nonlinearity of the ratio of equilibrium-fractionation factors and the crude approximation of $\ln (1+\delta) \sim \delta$. In contrast to the historical linear definition of $d$, recent studies of triple oxygen isotope study of water have used the logarithmic framework for defining the ${ }^{17} \mathrm{O}$-excess parameter (Barkan and Luz, 2007). Here, we examine how the historical definition of $d$ affects the ice core $d$ record and $\beta_{\text {site }}$ by introducing a logarithmic based definition of deuterium excess.

In the normal $\delta$ plot, the slope of Global Meteoric Water Line (GMWL) apparently keeps a constant value " 8 " along 

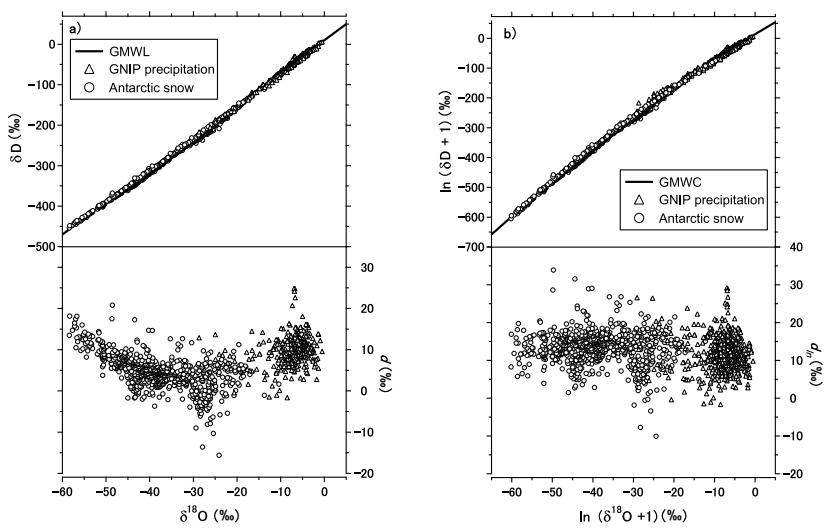

Fig. A1. Normal versus log plots for global meteoric water. (a) GMWL data from GNIP and Antarctic surface snow. GNIP data is based on 308 stations whose data contains the $d$ data longer than $2 \mathrm{yr}$. The GNIP data weighted by amount of precipitation give a recession line $\left(\delta \mathrm{D}=8.18 \times \delta^{18} \mathrm{O}+11.2\left(R^{2}=\right.\right.$ $0.991)$ ). (b) Same as (a) but plot on the log plot. All the data give a regression curve (GMWC): $\ln (1+\delta \mathrm{D})=-2.85 \times 10^{-2} \times(\ln$ $\left.\left(1+\delta^{18} \mathrm{O}\right)\right)^{2}+8.47 \times \ln \left(1+\delta^{18} \mathrm{O}\right)+13.3\left(R^{2}=0.999\right)$.

with isotope distillation (Craig, 1961). However, it is difficult to understand the physical meaning of this constant slope because the ratio of equilibrium fractionation-factors of hydrogen and oxygen $\left(\alpha_{\mathrm{D}}-1\right) /\left(\alpha_{18} d-1\right)$, which corresponds to the $\delta \mathrm{D} / \delta^{18} \mathrm{O}$ slope, increases from 8.7 to 9.6 when the temperature decreases from 20 to $0{ }^{\circ} \mathrm{C}$ (e.g. Jouzel, 1986). In principle, the increasing slope should be observed only in the $\log (1+\delta)$ plot. This point was clearly described in the historic GMWL paper (Craig, 1961) as "it is actually log $(1+\delta)$ which should be plotted for such a process.... The linear relation observed in Fig. 1 simply reflects a coincidence...". Recently, the limitation of normal $\delta$ diagrams is discussed in Miller (2002). In Antarctica, -50.0 and $-400 \%$ in $\delta$ notation (either $\delta^{18} \mathrm{O}$ or $\delta \mathrm{D}$ ) corresponds to -51.3 and $-511 \%$ o in $\log (1+\delta)$ notation, respectively. Thus, $\ln (1+\delta)$ cannot be approximated as $\delta$.

In order to show the differences of normal and logarithmic plot, global isotope data from Global Network of Isotopes in Precipitation (GNIP) database (e.g. Rozanski et al., 1993) and a recent compilation of Antarctic surface snow data (Masson-Delmotte et al., 2008) are shown in Fig. A1. Although, the GMWL appears to represent average isotopic composition, the slope is, in reality, non-linear. The $d$ data shows parabolic curve against $\delta^{18} \mathrm{O}$ with a minimum $(\sim$ negative values in $d)$ at $\sim-30 \%$ in $\delta^{18} \mathrm{O}$, and maxima $(\sim 15-20 \%$ in $d)$ at $\sim 0 \%$ o (equatorial) and $\sim-60 \%$ in $\delta^{18} \mathrm{O}$ (Antarctica) (Fig. A1a). Figure A1b shows the same data but on natural logarithmic plot. The data clearly show non-linear relationship between $\ln (1+\delta \mathrm{D})$ vs. $\ln \left(1+\delta^{18} \mathrm{O}\right)$. A simple quadric fitting gives sufficiently good representation as

$$
\begin{gathered}
\ln (1+\delta \mathrm{D})=-2.85 \times 10^{-2} \times\left(\ln \left(1+\delta^{18} \mathrm{O}\right)\right)^{2} \\
+8.47 \times \ln \left(1+\delta^{18} \mathrm{O}\right)+13.3\left(R^{2}=0.999\right) .
\end{gathered}
$$
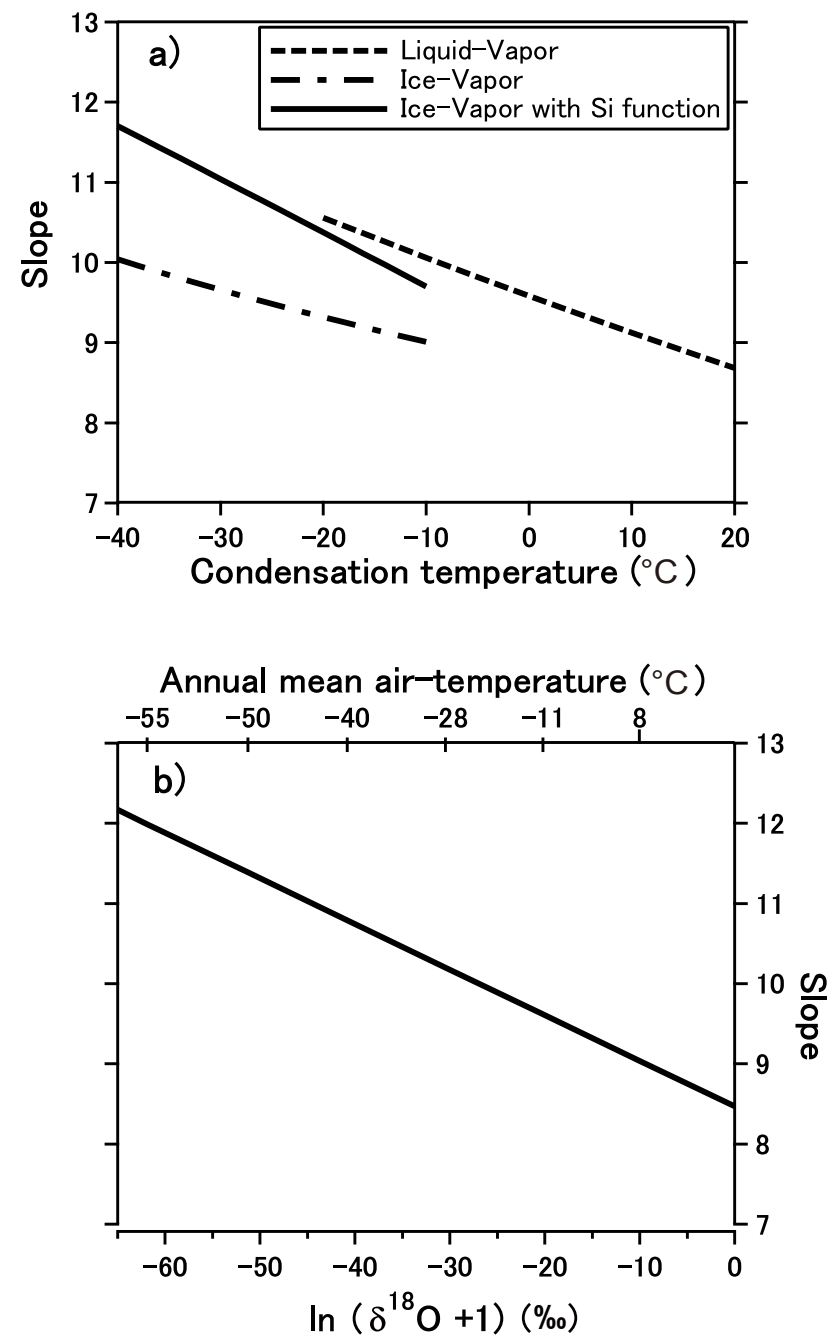

Fig. A2. Normal versus log plots for global meteoric water. The $\delta \mathrm{D} / \delta^{18} \mathrm{O}$ slope is calculated using a differential of Eq. (7) $\left(=-5.70 \times 10^{-2} \times \ln \left(1+\delta^{18} \mathrm{O}\right)+8.47\right)$. Kinetic fractionation during snow formation was considered using a super-saturation function (see text).

Unlike a constant slope of GMWL, the slope of this Global Meteoric Water Curve (GMWC) increases from $\sim 8.5$ to 12 as $\ln \left(1+\delta^{18} \mathrm{O}\right)$ decreases. Figure A2 shows the slope and $\ln \left(1+\delta^{18} \mathrm{O}\right)$ with corresponding annual-mean surface airtemperature. This slope generally agrees with the one expected from $\left(\alpha_{D}-1\right) /\left(\alpha_{18}-1\right)$. There is a clear gap between the transition of equilibrium fractionation factors for liquidvapor and ice-vapor for ${ }^{18} \mathrm{O}$ (Majoube, 1971a, b) and for $\mathrm{D}$ (Merlivat and Nief, 1967). The gap was narrowed after incorporating the super saturation effect (Jouzel and Merlivat, 1984) (here, we used the $S_{i}$ function described in Sect. 2.2. was used). 


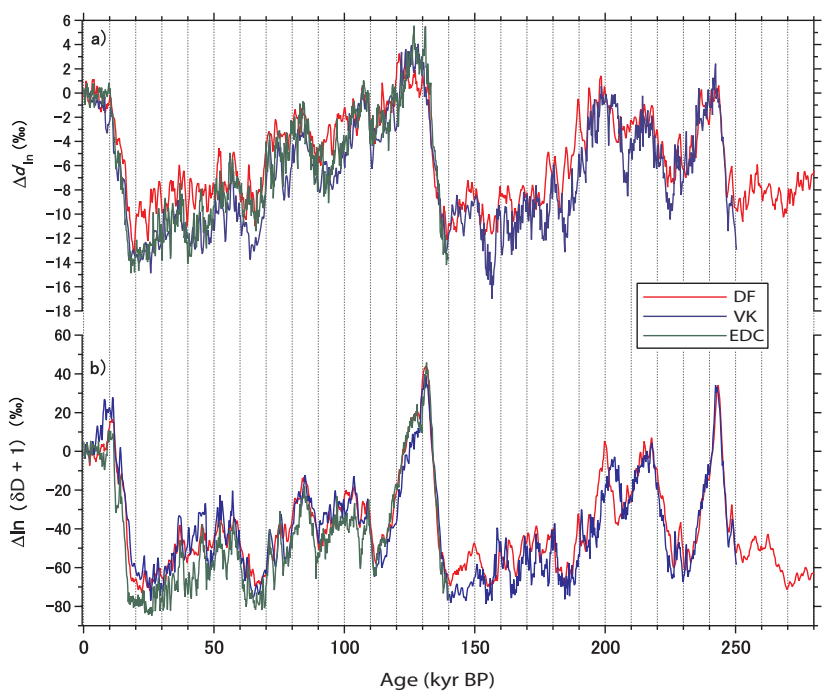

Fig. A3. Logarithmic defined deuterium-excess and $\delta \mathrm{D}$ records of Antarctic ice cores. (a) Deuterium-excess based on logarithmic expression $\left(d_{\mathrm{ln}}\right)$ records from DF (red line), Vostok (blue line), and EDC (green line) cores plotted on the $\mathrm{O}_{2} / \mathrm{N}_{2}$ orbital age scale for DF. (b) $\ln (\delta \mathrm{D}+1)$ records of the three cores plotted on the $\mathrm{O}_{2} / \mathrm{N}_{2}$ orbital age scale for DF.

Based on the GMWC, a deuterium-excess paramter based on logarithmic $\delta$, hereafter denoted as $d_{\ln }$, is defined as

$$
\begin{aligned}
d_{\ln } & =\ln (1+\delta \mathrm{D})-\left(-2.85 \times 10^{-2} \times\left(\ln \left(1+\delta^{18} \mathrm{O}\right)\right)^{2}\right. \\
& \left.+8.47 \times \ln \left(1+\delta^{18} \mathrm{O}\right)\right) .
\end{aligned}
$$

In contrast to the $d$, which shows parabolic curve against $\delta^{18} \mathrm{O}, d_{\ln }$ does not depend on $\ln \left(1+\delta^{18} \mathrm{O}\right)$ (Fig. A1b). Note that $d_{\mathrm{ln}}$ is defined based on phenomenological data set. Thus, not only the equilibrium effect but also kinetic fractionation (like snow formation effect) is also eliminated.

Figure A 3 shows the $d_{\ln }$ records of Antarctic ice cores. The $d_{\text {ln }}$ ranges from about -15 to $5 \%$. The glacialinterglacial amplitude is, thus, about two times larger than the normal $d$ variation. Unlike raw $d$ records, the $d_{\ln }$ records does not shows distinct $\sim 40 \mathrm{kyr}$ cycle nor the lag found in the glacial terminations. These results show that glacialinterglacial variations of $d$ record are sensitive to its definition. Thus, great care should be taken to interpret such second-order parameter.

With the same methodology used for the $d$, the $d_{\text {ln }}$ data can be converting to the $\Delta T_{\text {site }}$ and $\Delta T_{\text {source. }}$. For the correction for ocean isotope changes, $\ln (1+\delta)$ gives simpler formula than the case for normal $\delta$.

$\ln \left(1+\delta^{18} \mathrm{O}\right)_{\text {corr }}=\ln \left(1+\delta^{18} \mathrm{O}_{\text {ice }}\right)-\ln \left(1+\delta^{18} \mathrm{O}_{\mathrm{SW}}\right)$

$\ln (1+\delta \mathrm{D})_{\mathrm{corr}}=\ln \left(1+\delta \mathrm{D}_{\text {ice }}\right)-\ln \left(1+\delta \mathrm{D}_{\mathrm{SW}}\right)$.

Here, $\ln \left(1+\delta^{18} \mathrm{O}\right)_{\text {corr }}$ and $\ln (1+\delta \mathrm{D})_{\text {corr }}$ are the isotope ratios of the ice corrected for ocean isotope changes. The $\delta \mathrm{D}_{\mathrm{SW}}$ can be calculated on the assumption that $\ln \left(\delta \mathrm{D}_{\mathrm{sw}}+1\right)=-2.85 \times 10^{-2} \times\left(\ln \left(1+\delta^{18} \mathrm{O}_{\mathrm{sw}}\right)\right)^{2}+$ $8.47 \times \ln \left(1+\delta^{18} \mathrm{O}_{\mathrm{sw}}\right)$. Thus, the $d_{\mathrm{ln}}$ value corrected for the ocean isotope effect $\left(d_{\text {ln_corr }}\right)$ can be obtained by substituting $\left(1+\delta^{18} \mathrm{O}\right)_{\text {corr }}$ and $(1+\delta \mathrm{D})_{\text {corr }}$ to the Eq. (A2). Then, the isotope inversion was performed to retreive the $\Delta T_{\text {site }}$ and $\Delta T_{\text {source }}$ information. The relations obtained for the DF ice core are

$$
\begin{gathered}
\Delta \ln (1+\delta D)_{\text {corr }}=13.5 \Delta T_{\text {site }}-5.5 \Delta T_{\text {source }} \\
\left(R^{2}=0.999, n=14, p<0.001\right) \\
\Delta d_{\ln \_ \text {corr }}=-0.4 \Delta T_{\text {site }}+1.8 \Delta T_{\text {source }} \\
. \quad\left(R^{2}=0.996, n=14, p<0.001\right)
\end{gathered}
$$

We should note that we only modified the notation of $\delta$ and the definition of $d$. The two primary data sets ( $\delta \mathrm{D}$ and $\left.\delta^{18} \mathrm{O}\right)$ and inversion methodology are the same. Therefore, the $\Delta T_{\text {site }}$ and $\Delta T_{\text {source }}$ obtained based on the Eqs. (A5) and (A6) are identical with those of obtained based on the Eqs. (5) and (6). The values of coefficients of the Eqs. (A5) and (A6) differ from those of Eqs. (5) and (6). The coefficient $\beta_{\text {site }}(0.4)$ is significantly smaller than our estimation (1.3). This result clearly shows the fact that the value of $\beta_{\text {site }}$ significantly depends on the definition of deuterium excess. In other word, $\beta_{\text {site }}$ act as a correction factor for the empirically defined $d$ parameter. Detailed and comprehensive analysis of $d_{\ln }$ (e.g. other Antarctic sites, Greenland ice cores, and golobal precipitation) is beyond the scope of this manuscript. At least for the case of DF, the smaller $\beta_{\text {site }}$ value indicates that the $d_{\ln }$ is better representation of source effect. In general, $d_{\ln }$ would be suitable for comparison with similarly defined parameter, ${ }^{17} \mathrm{O}$-excess.

Acknowledgements. We thank DF ice core group, Maki Nakada, Hironobu Yamada and Satoru Kikuchi for supporting isotopic measurement. We also thank Alexey Ekaykin and Françoise Vimeux for comments. We thank Dae-Yeol Baek for drawing the map. This research was supported by JSPS Postdoctoral Fellowships for Research Abroad and by a Grant-in-Aid for scientific research (S)(21221002) from the Ministry of Education, Science, Sports and Culture, Japan and the French ANR Dome A project.

Edited by: N. Abram

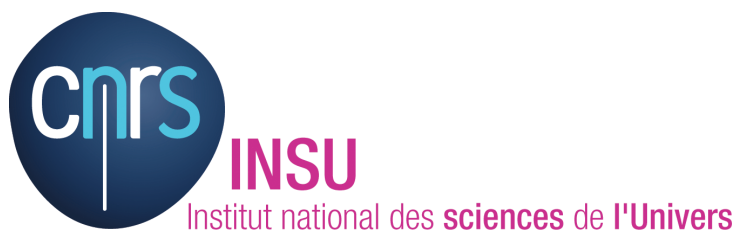

The publication of this article is financed by CNRS-INSU. 


\section{References}

Antico, A., Marchal, O., Mysak, L. A., and Vimeux, F.: Milankovitch Forcing and Meridional Moisture Flux in the Atmosphere: Insight from a Zonally Averaged Ocean - Atmosphere Model, J. Climate, 23, 4841-4855, doi:10.1175/2010JCLI3273.1, 2010.

Barkan, E. and Luz, B.: Diffusivity fractionations of $\mathrm{H}_{2}^{16} \mathrm{O} / \mathrm{H}_{2}^{17} \mathrm{O}$ and $\mathrm{H}_{2}^{16} \mathrm{O} / \mathrm{H}_{2}^{18} \mathrm{O}$ in air and their implications for isotope hydrology, Rapid Commun. Mass Spectrom., 21, 2999-3005, doi:10.1002/rcm.3180, 2007.

Barrows, T. T., Juggins, S., Deckker, P. D., Calvo, E., and Pelejero, C.: Long-term sea surface tempearture and climate change in the Austrarian-New Zealand region, Paleoceanography, 22, PA2215, doi:10.1029/2006PA001328, 2007.

Bintanja, R. and Wal, R. S. W. V. D.: North American ice-sheet dynamics and the onset of 100,000-year glacial cycles, Nature, 454, 869-872, doi:10.1038/nature07158, 2008.

Boyle, E. A.: Cool tropical temperatures shift the global $\delta^{18} \mathrm{O}-\mathrm{T}$ relationship: An explanation for the ice core $\delta^{18} \mathrm{O}-$ borehole thermometry conflict?, Geophys. Res. Lett., 24, 273-276, 1997.

Ciais, P. and Jouzel, J.: Deuterium and oxygen 18 in precipitation: Isotopic model, including mixed cloud processes, J. Geophys. Res., 99, 16793-16803, 1994.

Cortijo, E., Lehman, S., Keigwin, L., Chapman, M., Paillard, D., and Labeyrie, L.: Changes in Meridional Temperature and Salinity Gradients in the North Atlantic Ocean $\left(30^{\circ}-72^{\circ} \mathrm{N}\right)$ during the Last Interglacial Period, Paleoceanography, 14, 23-33, doi:10.1029/1998PA900004, 1999.

Craig, H.: Isotopic variations in meteoric waters, Science, 133, 1702-1703, 1961.

Cuffey, K. M. and Vimeux, F.: Covariation of carbon dioxide and temperature from the Vosotok ice core after deuterium-excess correction, Nature, 412, 523-527, 2001.

Dansgaard, W.: Stable isotopes in precipitation, Tellus, 16, 436468, 1964.

Davis, B. A. S. and Brewer, S.: Orbital forcing and role of the latitudinal insolation/temperature gradient, Clim. Dynam., 32, 143165, doi:10.1007/s00382-008-0480-9, 2009.

Delaygue, G., Masson, V., Jouzel, J., and Koster, R. D.: The origin of Antarctic precipitation: a modelling approach, Tellus, 52B, 19-36, 2000.

Ekaykin, A. A.: Meteorological regime of central Antarctic and its role in the formation of isotope composition of snow thickness, Ph. D., University Joseph Fourier, Grenoble, 2003.

Ellehoj, M. D., Johnsen, S. J., Steen-Larsen, H. C., and Madsen, M. B.: Ice-vapor equilibrium fractionation factor of hydrogen and oxygenisotopes: Experimental investigations and implications for stable water isotope studies, submitted, GeochimicaetCosmochimicaActa, 2012.

Epica community members: Eight glacial cycles from an Antarctic ice core, Nature, 429, 623-628, doi:10.1029/2002JD003147, 2004.

Fujita, K. and Abe, O.: Stable isotopes in daily precipitation at Dome Fuji, East Antarctica, Geophys. Res. Lett., 33 L18503, doi:10.1029/2006GL026936, 2006.

Fujita, S., Holmlund, P., Andersson, I., Brown, I., Enomoto, H., Fujii, Y., Fujita, K., Fukui, K., Furukawa, T., Hansson, M., Hara, K., Hoshina, Y., Igarashi, M., Iizuka, Y., Imura, S., Ingvander,
S., Karlin, T., Motoyama, H., Nakazawa, F., Oerter, H., Sjöberg, L. E., Sugiyama, S., Surdyk, S., Ström, J., Uemura, R., and Wilhelms, F.: Spatial and temporal variability of snow accumulation rate on the East Antarctic ice divide between Dome Fuji and EPICA DML, The Cryosphere, 5, 1057-1081, doi:10.5194/tc-51057-2011, 2011.

Fukui, K., Uemura, R., Fujita, S., and Motoyama, H.: Distribution of stable isotopes in surface snow on the plateau of East Dronning Maud Land, Antarctica, observed by Japanese-Swedish traverse expedition 2007/08, Abstracts of International symposium on Snow, Ice, and Humanity in a changing climate, International Glaciological Society, 101 pp., 2010.

Huybers, P. and Wunsch, C.: Obliquity pacing of the late Pleistocene glacial terminations, Nature, 434, 491-494, doi:10.1038/nature03401, 2005.

Jouzel, J.: Isotopes in cloud physics: Multistep and multistage processes, The terrestrial Environment B, in: Handbook of Environmental Isotope Geochemistry, Elsevier, New York, 61-112, 1986.

Jouzel, J. and Merlivat, L.: Deuterium and oxygen 18 in precipitation: Modeling of the isotopic effects during snow formation, J. Geophys. Res., 89, 11749-11757, 1984.

Jouzel, J., Vimeux, F., Caillon, N., Delaygue, G., Hoffmann, G., Masson-Delmotte, V., and Parrenin, F.: Magnitude of isotope/temperature scaling for interpretation of central Antarctic ice cores, J. Geophys. Res., 108, 4361, doi:10.1029/2002JD002677, 2003.

Jouzel, J., Masson-Delmotte, V., Cattani, O., Dreyfus, G., Falourd, S., Hoffmann, G., Minster, B., Nouet, J., Barnola, J. M., Chappellaz, J., Fischer, H., Gallet, J. C., Johnsen, S., Leuenberger, M., Loulergue, L., Luethi, D., Oerter, H., Parrenin, F., Raisbeck, G., Raynaud, D., Schilt, A., Schwander, J., Selmo, E., Souchez, R., Spahni, R., Stauffer, B., Steffensen, J. P., Stenni, B., Stocker, T. F., Tison, J. L., Werner, M., and Wolff, E. W.: Orbital and Millennial Antarctic Climate Variability over the Past 800,000 Years, Science, 317, 793-796, doi:10.1126/science.1141038, 2007.

Kavanaugh, J. L. and Cuffey, K. M.: Space and time variation of $\delta^{18} \mathrm{O}$ and $\delta \mathrm{D}$ in Antarctic precipitation revisited, Global Biogeochem. Cy., 17, 1017, doi:10.1029/2002GB001910, 2003.

Kawamura, K., Parrenin, F., Lisiecki, L., Uemura, R., Vimeux, F., Severinghaus, J. P., Hutterli, M., Nakazawa, T., Aoki, S., Jouzel, J., Raymo, M. E., Matsumoto, K., Nakata, H., Motoyama, H., Fujita, S., Goto-Azuma, K., Fujii, Y., and Watanabe, O.: Northern Hemisphere forcing of climatic cycles in Antarctica over the past 360,000 years, Nature, 448, 912-916, doi:10.1038/nature06015, 2007.

Khodri, M., Leclainche, Y., Ramstein, G., Braconnot, P., Marti, O., and Cortijo, E.: Simulating the amplification of orbital forcing by ocean feedbacks in the last glaciation, Nature, 410, 570-574, 2001.

Labeyrie, L., Labracherie, M., Gorfti, N., Pichon, J. J., Vautravers, M., Arnold, M., Duplessy, J.-C., Paterne, M., Michel, E., Duprat, J., Caralp, M., and Turon, J.-L.: Hydrographic changes of the Southern Ocean (southeast Indian sector) over the last $230 \mathrm{kyr}$, Paleoceanography, 11, 57-76, 1996.

Laepple, T., Werner, M., and Lohmann, G.: Synchronicity of Antarctic temperatures and local solar insolation on orbital timescales, Nature, 471, 91-94, doi:10.1038/nature09825, 2011. 
Landais, A., Barkan, E., and Luz, B.: Record of $\delta^{18} \mathrm{O}$ and ${ }^{17} \mathrm{O}$-excess in ice from Vostok Antarctica during the last 150,000 years, Geophys. Res. Lett., 35, L02709, doi:10.1029/2007GL032096, 2008.

Landais, A., Barkan, E., Vimeux, F., Masson-Delmotte, V., and Luz, B.: Combined Analysis of Water Stable Isotope $\left(\mathrm{H}_{2}^{16} \mathrm{O}, \mathrm{H}_{2}^{17} \mathrm{O}\right.$, $\mathrm{H}_{2}^{18} \mathrm{O}, \mathrm{HD}^{16} \mathrm{O}$ ) in Ice Cores, in: Physics of Ice-Core Records II, edited by: Hondoh, T., Institue of Low Temperature Science, Hokkaido University Press, Sapporo, 315-327, 2009.

Landais, A., Steen-Larsen, H. C., Guillevic, M., MassonDelmotte, V., Vinther, B., and Winkler, R.: Triple isotopic composition of oxygen in surface snow and water vapor at NEEM (Greenland), Geochim. Cosmochim. Ac., 77, 304-316, doi:10.1016/j.gca.2011.11.022, 2011.

Lee, S.-Y. and Poulsen, C. J.: Amplification of obliquity forcing through mean annual and seasonal atmospheric feedbacks, Clim. Past, 4, 205-213, doi:10.5194/cp-4-205-2008, 2008.

Loutre, M.-F., Paillard, D., Vimeux, F., and Cortijo, E.: Does mean annual insolation have the potential to change the climate?, Earth Planet. Sci. Lett., 221, 1-14, doi:10.1016/S0012821X(04)00108-6, 2004.

Luz, B. and Barkan, E.: Variations of ${ }^{17} \mathrm{O} /{ }^{16} \mathrm{O}$ and ${ }^{18} \mathrm{O} /{ }^{16} \mathrm{O}$ in meteoric waters, Geochim. Cosmochim. Ac., 74, 6276-6286, doi:10.1016/j.gca.2010.08.016, 2010.

Luz, B., Barkan, E., Yam, R., and Shemesh, A.: Fractionation of oxygen and hydrogen isotopes in evaporating water, Geochim. Cosmochim. Ac., 73, 6697-6703, doi:10.1016/j.gca.2009.08.008, 2009.

Majoube, M.: Fractionnement en oxygène-18 et en deutérium entre l'eau et sa vapeur, Journale de Chimie Physique, 68, 1423-1436, 1971a.

Majoube, M.: Fractionnement en oxygène-18 entre la glace et la vapeur d'eau, Journale de Chimie Physique, 68, 625-636, 1971 b.

Margo project members: Constraints on the magnitude and patterns of ocean cooling at the Last Glacial Maximum, Nat. Geosci., 2, 127-132, doi:10.1038/NGEO411, 2009.

Masson-Delmotte, V., Stenni, B., and Jouzel, J.: Common millenialscale variability of Antarctic and Southern Ocean temperatures during the past 5000 years reconstructed from the EPICA Dome C ice core, The Holocene, 14, 145-151, 2004.

Masson-Delmotte, V., Hou, S., Ekaykin, A., Jouzel, J., Aristarain, A., Bernardo, R. T., Bromwich, D., Cattani, O., Delmotte, M., Falourd, S., Frezzotti, M., GallÉe, H., Genoni, L., Isaksson, E., Landais, A., Helsen, M. M., Hoffmann, G., Lopez, J., Morgan, V., Motoyama, H., Noone, D., Oerter, H., Petit, J. R., Royer, A., Uemura, R., Schmidt, G. A., Schlosser, E., SimÕes, J. C., Steig, E. J., Stenni, B., Stievenard, M., Broeke, M. R. V. D., Wal, R. S. W. V. D., Berg, W. J. V. D., Vimeux, F., White, J. W. C., and Vimeux, F.: A Review of Antarctic Surface Snow Isotopic Composition: Observations, Atmospheric Circulation, and Isotopic Modeling, J. Climate, 21, 3359-3387, doi:10.1175/2007JCLI2139.1, 2008.

Masson-Delmotte, V., Stenni, B., Blunier, T., Cattani, O., Chappellaz, J., Cheng, H., Dreyfus, G., Edwards, R. L., Falourd, S., Govin, A., Kawamura, K., Johnsen, S. J., Jouzel, J., Landais, A., Lemieux-Dudon, B., Lourantou, A., Marshall, G., Minster, B., Mudelsee, M., Pol, K., Rothlisberger, R., Selmo, E., and Waelbroeck, C.: Abrupt change of Antarctic moisture origin at the end of Termination II, Proc. Natl. Acad. Sci. USA, 107, 12091-
12094, doi:10.1073/pnas.0914536107, 2010a.

Masson-Delmotte, V., Stenni, B., Pol, K., Braconnot, P., Cattani, O., Falourd, S., Kageyama, M., Jouzel, J., Landais, A., Minster, B., Barnola, J. M., Chappellaz, J., Krinner, G., Johnsen, S., Röthlisberger, R., Hansen, J., Mikolajewicz, U., and Otto-Bliesner, B.: EPICA Dome $\mathrm{C}$ record of glacial and interglacial intensities, Quaternary Sci. Rev., 29, 113-128, doi:10.1016/j.quascirev.2009.09.030, 2010b.

Masson-Delmotte, V., Buiron, D., Ekaykin, A., Frezzotti, M., Gallée, H., Jouzel, J., Krinner, G., Landais, A., Motoyama, H., Oerter, H., Pol, K., Pollard, D., Ritz, C., Schlosser, E., Sime, L. C., Sodemann, H., Stenni, B., Uemura, R., and Vimeux, F.: A comparison of the present and last interglacial periods in six Antarctic ice cores, Clim. Past, 7, 397-423, doi:10.5194/cp-7397-2011, 2011.

Merlivat, L. and Jouzel, J.: Global climatic interpretation of the deuterium-oxygen 18 relationship for precipitation, J. Geophys. Res., 84, 5029-5033, 1979.

Merlivat, L. and Nief, G.: Fractionnement isotopique lors des changements d'état solide-vapeur et liquide-vapeur de l'eau à des températures inférieures à $0^{\circ} \mathrm{C}$, Tellus, 19, 122-127, 1967.

Miller, M. F.: Isotopic fractionation and the quantification of ${ }^{17} \mathrm{O}$ anomalies in the oxygen three-isotope system: an appraisal and geochemical significance, Geochim. Cosmochim. Ac., 66, 18811889, 2002.

Motoyama, H.: The Second Deep Ice Coring Project at Dome Fuji, Antarctica, Scientific Drilling, 5, 41-43, doi:10.2204/iodp.sd.5.05.2007, 2007.

Motoyama, H., Hirasawa, N., Satow, K., and Watanabe, O.: Seasonal variations in oxygen isotope ratios of daily collected precipitation and wind drift samples and in the final snow cover at Dome Fuji Station, Antarctica, J. Geophys. Res., 110, D11106, doi:10.1029/2004JD004953, 2005.

Pahnke, K. and Sachs, J. P.: Sea surface tempearatures of southern midlatitudes 0-160 kyr B.P., Paleoceanography, 21, PA2003, doi:10.1029/2005PA001191, 2006.

Paillard, D., Labeyrie, L., and Yiou, P.: Macintosh Program performs time-series analysis, Eos Trans. AGU, 77, 379, 1996.

Parrenin, F., Barnola, J.-M., Beer, J., Blunier, T., Castellano, E., Chappellaz, J., Dreyfus, G., Fischer, H., Fujita, S., Jouzel, J., Kawamura, K., Lemieux-Dudon, B., Loulergue, L., MassonDelmotte, V., Narcisi, B., Petit, J.-R., Raisbeck, G., Raynaud, D., Ruth, U., Schwander, J., Severi, M., Spahni, R., Steffensen, J. P., Svensson, A., Udisti, R., Waelbroeck, C., and Wolff, E.: The EDC3 chronology for the EPICA Dome C ice core, Clim. Past, 3, 485-497, doi:10.5194/cp-3-485-2007, 2007.

Petit, J. R., White, J. W. C., Young, N. W., Jouzel, J., and Korotkevich, Y. S.: Deuterium excess in recent Antarctic snow, J. Geophys. Res., 96, 5113-5122, 1991.

Petit, J. R., Jouzel, J., Raynaud, D., Barkov, N. I., Barnola, J.-M., Basile, I., Bender, M., Chappellaz, J., Davisk, M., Delaygue, G., Delmotte, M., Kotlyakov, V. M., Legrand, M., Lipenkov, V. Y., Lorius, C., PeÂpin, L., Ritz, C., Saltzmank, E., and Stievenard, M.: Climate and atmospheric history of the past 420,000 years from the Vostok ice core, Antarctica, Nature, 399, 429436, 1999.

Pol, K., Debret, M., Masson-Delmotte, V., Capron, E., Cattani, O., Dreyfus, G., Falourd, S., Johnsen, S., Jouzel, J., Landais, A., Minster, B., and Stenni, B.: Links between MIS 11 millennial 
to sub-millennial climate variability and long term trends as revealed by new high resolution EPICA Dome $\mathrm{C}$ deuterium data - A comparison with the Holocene, Clim. Past, 7, 437-450, doi:10.5194/cp-7-437-2011, 2011.

Raymo, M. E. and Nisancioglu, K.: The 41 kyr world: Milankovitch's other unsolved mystery, Paleoceanography, 18, 1011, doi:10.1029/2002PA000791, 2003.

Reijmer, C. H., Broeke, M. R. V. D., and Scheele, M. P.: Air Parcel Trajectories and Snowfall Related to Five Deep Drilling Locations in Antarctica Based on the ERA-15 Dataset, J. Climate, 15, 1957-1968, 2002.

Risi, C., Landais, A., Bony, S., Jouzel, J., Masson-Delmotte, V., and Vimeux, F.: Understanding the ${ }^{17} \mathrm{O}$ excess glacial - interglacial variations in Vostok precipitation, J. Geophys. Res., 115, D10112, doi:10.1029/2008JD011535, 2010.

Rozanski, K., Araguás-Araguás, L., and Gonfiantini, R.: Isotopic patterns in modern global precipitation, in: Climate Changes in Continental Isotopic Records, edited by: Swart, P. K., Lohmann, K. C., McKenzie, J., and Savin, S., Geophysical Monograph, 78, American Geophysical Uniton, Washington DC, 1-36, 1993.

Sachs, J. P., Anderson, R., F., and Lehman, S., J.: Glacial Surface Tempearture of the Southeast Atlantic Ocean, Science, 293, 2077-2079, 2001.

Salamatin, A. N., Ekaykin, A. A., and Lipenkov, V. Y.: Modelling isotopic composition in precipitation in Central Antarctica, Mater. Glyatsiol. Issled., 97, 24-34, 2004.

Sime, L. C., Wolff, E. W., Oliver, K. I. C., and Tindall, J. C.: Evidence for warmer interglacials in East Antarctic ice cores, Nature, 462, 342-345, doi:10.1038/nature08564, 2009.

Skinner, L. C., Fallon, S., Waelbroeck, C., Michel, E., and Barker, S.: Ventilation of the Deep Southern Ocean and Deglacial $\mathrm{CO}_{2}$ Rise, Science, 328, 1147-1151, doi:10.1126/science.1183627, 2010.

Sodemann, H. and Stohl, A.: Asymmetries in the moisture origin of Antarctic precipitation, Geophys. Res. Lett., 36, L22803, doi:10.1029/2009GL040242, 2009.

Steig, E. J., Grootes, P. M., and Stuiver, M. S.: Seasonal Precipitation Timing and Ice Core Records, Science, 266, 1885-1886 doi:10.1126/science.266.5192.1885, 1994.

Stenni, B., Masson-Delmotte, V., Johnsen, S., Jouzel, J., Longinelli, A., Monnin, E., Röthlisberger, R., and Selmo, E.: An oceanic cold reversal during the last deglaciation, Science, 293, 20742077, 2001.

Stenni, B., Jouzel, J., Masson-Delmotte, V., Röthlisberger, R., Castellano, E., Cattani, O., Falourd, S., Johnsen, S. J., Longinelli, A., Sachs, J. P., Selmo, E., Souchez, R., Steffensen, J. P., and Udisti, R.: A late-glacial high-resolution site and source temperature record derived from the EPICA Dome C isotope records (East Antarctica), Earth Planet. Sci. Lett., 217, 183-195, doi:10.1016/S0012-821X(03)00574-0, 2003.

Stenni, B., Masson-Delmotte, V., Selmo, E., Oerter, H., Meyer, H., Röthlisberger, R., Jouzel, J., Cattani, O., Falourd, S., and Fischer, H.: The deuterium excess records of EPICA Dome C and Dronning Maud Land ice cores (East Antarctica), Quaternary Sci. Rev., 29, 146-159, doi:10.1016/j.quascirev.2009.10.009, 2010.
Tzedakis, P. C., Roucoux, K. H., De Abreu, L., and Shackleton, N. J.: The Duration of Forest Stages in Southern Europe and Interglacial Climate Variability, Science, 306, 2231-2235, doi:10.1126/science.1102398, 2004.

Uemura, R., Yoshida, N., Kurita, N., Nakawo, M., and Watanabe, O.: An observation-based method for reconstructing ocean surface changes using a 340,000-year deuterium excess record from the Dome Fuji ice core, Antarctica, Geophys. Res. Lett., 31, L13216, doi:10.1029/2004GL019954, 2004.

Uemura, R., Matsui, Y., Motoyama, H., and Yoshida, N.: Deuterium and oxygen-18 determination of microliter quantities of a water sample using an automated equilibrator, Rapid Commun. Mass Sp., 21, 1783-1790, doi:10.1002/rcm.3022, 2007.

Uemura, R., Matsui, Y., Yoshimura, K., Motoyama, H., and Yoshida, N.: Evidence of deuterium excess in water vapor as an indicator of ocean surface conditions, J. Geophys. Res., 113, D19114, doi:10.1029/2008JD010209, 2008.

Uemura, R., Abe, O., and Motoyama, H.: Determining the ${ }^{17} \mathrm{O} /{ }^{16} \mathrm{O}$ ratio of water using a water- $\mathrm{CO}_{2}$ equilibration method: Application to glacial-interglacial changes in ${ }^{17} \mathrm{O}$-excess from the Dome Fuji ice core, Antarctica, Geochim. Cosmochim. Ac., 74, 49194936, doi:10.1016/j.gca.2010.05.007, 2010a.

Uemura, R., Barkan, E., Abe, O., and Luz, B.: Triple isotope composition of oxygen in atmospheric water vapor, Geophys. Res. Lett., 37, L04402, doi:10.1029/2009g1041960, $2010 \mathrm{~b}$.

Vázquez Riveiros, N., Waelbroeck, C., Skinner, L., Roche, D. M., Duplessy, J.-C., and Michel, E.: Response of South Atlantic deep waters to deglacial warming during Terminations V and I, Earth Planet. Sci. Lett., 298 323-333, doi:10.1016/j.eps1.2010.08.003, 2010.

Vimeux, F., Masson, V., Jouzel, J., Stievenard, M., and Petit, J. R.: Glacial-interglacial changes in ocean surface conditions in the Southern Hemisphere, Nature, 398, 410-413, 1999.

Vimeux, F., Masson, V., Delaygue, G., Jouzel, J., Petit, J. R., and Stievenard, M.: A 420,000 year deuterium excess record from East Antarctica: Information on past changes in the origin of precipitation at Vostok, J. Geophys. Res., 106, 31863-31873, 2001.

Vimeux, F., Cuffey, K. M., and Jouzel, J.: New insights into Southern Hemisphere temperature changes from Vostok ice cores using deuterium excess correction, Earth Planet. Sci. Lett., 203, 829-843, doi:10.1016/S0012-821X(02)00950-0, 2002.

Watanabe, O., Jouzel, J., Johnsen, S., Parrenin, F., Shoji, H., and Yoshida, N.: Homogeneous climate variability across East Antarctica over the pasta three glacial cycles, Nature, 422, 509512, 2003.

Winkler, R., Landais, A., Sodemann, H., Dümbgen, L., Prié, F., Masson-Delmotte, V., Stenni, B., and Jouzel, J.: Deglaciation records of 17O-excess in East Antarctica: reliable reconstruction of oceanic normalized relative humidity from coastal sites, Clim. Past, 8, 1-16, doi:10.5194/cp-8-1-2012, 2012. 